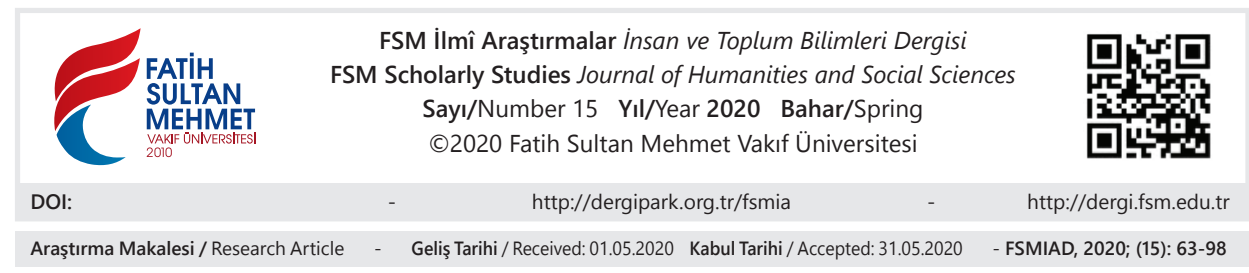

\title{
1712 Tarihli Avârız Defterine Göre Bergos (Lüleburgaz) Kazası
}

Bekir Gökpınar*

\section{Öz}

Bergos, Rumeli'de ilk fethedilen yerlerden biri olup fethinden itibaren Vize sancăğna bağlı bir kazadır. XVII. yüzyıl başlarından itibaren avârız tahrirleri önem kazanmıştır. Bu kapsamda 1712 yılında Bergos kazasının tahriri yapılarak avârız defteri hazırlanmıştır. Bu çalışmada söz konusu avârız defteri esas alınarak Bergos kazasının merkezinde bulunan mahallelerdeki askerî görevliler, din görevlileri, fakir ve yoksul nüfusun durumu incelenmiştir. Yine Bergos kazası köylerinin tahsis edildiği selâtîn ve ümerâ vakıfları da konu edilmiştir. Yapılan tahrir sonucu vergi tabanını esas olan nüfus ve avârız hânesi tespit edilerek değerlendirmeye tabi tutulmuştur.

Anahtar Kelimeler: Osmanlı, Rumeli, kaza, Bergos, avârız, tahrir.

\section{The Jurisdiction of Bergos According to the Awarid Register Dated 1712}

\section{Abstract}

Bergos is one of the first conquered places in Rumelia and it is an district appendant to the Vize Province since its conquest. As of the beginning of the XVII. century, avariz

\footnotetext{
* Dr., İstanbul/Türkiye, bgokpinar@gmail.com, orcid.org/0000-0003-1017-6037
} 
registers have gained importance. In this context, the avariz register was prepared in 1712 by the of the Bergos district. In this paper, the status of the military officers, religious officials, poor and pauper population in the quarters located in the center of the Bergos district, based on the said registry. Also, the foundations of the sultans and commanders where the villages of Bergos were allocated were also discussed. As a result of the registration, the potential tax payers and avarı household payers, , were determined and evaluated.

Keywords: Ottoman, Rumeli, kaza, Bergos, avariz, tahrir. 


\section{Giriş}

Bergos, Yunanca bir kelime olup kale anlamındadır. Günümüzde Lüleburgaz olarak Kırklareli’ne bağlı bir ilçe olan Bergos, Osmanlı'nın Doğu Trakya’yı fethetmesi ile birlikte 1357-1361 yıllarında alındı. İlk defa Orhan Bey zamanında 1357 yılında Bizanslılar'dan alındıysa da sonra elden çıkmıştır. Kesin olarak fethedilmesi I. Murad döneminde 1361 yılında gerçekleşmiştir. Osmanlı'nın Lüleburgaz' 1 ele geçirmesi ile birlikte Trakya'da yeni fetih imkanları ortaya çıkmıştır. Bergos'tan sonra Edirne fethedilmiş, böylelikle başkent Bursa'dan Edirne'ye taşınmıştır. Daha sonra Vize, Kırklareli, Sizebolu kaleleri de alınarak Trakya'da Türk yerleşimi tamamlanmıştır. ${ }^{1}$

Osmanlı'nın Rumeli'nin fethini müteakip muhtelif yörük grupları da buralara geçerek yerleşmeye başlamıştır. Yörük gruplarının zamanla Rumeli' de artan nüfus ve önemleri sebebiyle kendilerine has bir askeri teşkilat, nizam ve kanunnameler oluşturulma ihtiyacı ortaya çıkmıştır. Söz konusu yörük grupları arasında Vize yörük grupları da mevcut olup, bunların yerleşim sahaları arasında Bergos da yer almaktadır. ${ }^{2}$ Bunun yanında Osmanlı, Doğu Trakya kısmını feth ettiği andan itibaren yeni oluşturulan Rumeli eyaletine bağlı ilk sancaklar; Vize, Kırkkilise ve Çirmen' dir. ${ }^{3}$ Bergos ise daha ilk başlardan itibaren Osmanlı idarî taksimatı içerisinde Vize sancağına bağlı kaza olarak yer almıştır. Nitekim Kanûnî Sultan Süleyman devri başlarında hazırlanan 1522 tarihli Osmanlı idarî taksimatının yer aldığı deftere göre Vize sancağına bağlı kazalar Silivri, Çorlu, Hayrabolu, Burgaz (Lüleburgaz), Baba-eskisi, Pınar-hisar ve Kırk-kilise idi. ${ }^{4}$ Bunu müteakiben 1527-1528 yıllarında yapılan başka bir taksimatta ise Bergos, Vize sancağına bağl1 10 kazadan biri olarak kayıtlarda mevcuttur. ${ }^{5}$ Hakeza XVI. yüzyıla ait Os-

1 Machiel Kiel, "Lüleburgaz”, Türkiye Diyanet Vakfi İslam Ansiklopedisi (TDVIAA), c. 27, Ankara, 2003, s. 255-256; Nihan Purodran, “Temettuat Defterlerine Göre Lüleburagz’nn Sosyo-Ekonomik ve Demografik Yapısı”, (Yayımlanmamış Yüksek Lisans Tezi), Trakya Üniversitesi Sosyal Bilimler Enstitüsü, Edirne, 2010, s. 10.

2 Rumeli'deki yörük grupları; Naldöken, Tanrıdağı, Selanik, Ofçabolu ve Vize yörüklerinden oluşmaktadır. M. Tayyip Gökbilgin, Rumeli'de Yörükler, Tatarlar ve Evlad-ı Fatihân, İstanbul, İstanbul Üniversitesi Edebiyat Fakültesi Yayınlar1, 1957, s. 8485-.

3 M. Tayyip Gökbilgin, XV-XVI.Asırlarda Edirne ve Paşa Livası (Vakıflar-Mülkler-Muktaalar), İstanbul, İstanbul Üniversitesi Edebiyat Fakültesi Yayınları, 1952, s. 7.

4 Enver Çakar, "Kanûni Sultan Süleyman Kanun-nâmesine Göre 1522 Y1lında Osmanlı İmparatorluğu'nun İdarî Taksimatı", Firat Üniversitesi Sosyal Bilimler Dergisi, c. 12/1, Elazı̆̆, 2002, s. 268.

5 M. Tayyip Gökbilgin, "Kanûnî Sultan Süleyman Devri Başlarında Rumeli Eyaleti, Livaları, Şehir ve Kasabaları", Belleten, cilt 20, sayı 78, Ankara, 1956, s. 255. 
manlı idarî taksimatı ile ilgili Tahrir ve Ruus Defterlerine dayalı yayınlamış diğer kaynaklarda da Bergos, Vize sancağına tabi kazalardan biridir. ${ }^{6}$ Bergos nahiyesi kadılık statüsüne 8 Şubat 1569 (21 Şaban 976) tarihinde çıkarılmıştır. Bununla birlikte Vize, Hayrabolu, Babaeskisi, Çorlu ve Pınarhisar kadılıklarından 41 köy ayrılarak Bergos kazasına bağlanmıştır. ${ }^{7}$ Bergos'un Vize'ye bağlı bir kaza statüsü XVII. ve XVIII. yüzyıllar boyunca değişmeden devam etmiştir. ${ }^{8}$

Bergos'un tarih boyunca dikkat çeken diğer bir özelliği İstanbul-Edirne arasındaki menzil güzergahı üzerinde bulunmasıdır. Osmanlı döneminde Rumeli yol şebekesi Edirne'den sonra üçe ayrılmaktadır. Sağ kol Özi-Kırım, sol kol İstefe-Gördüs, orta kol ise Belgrad'a kadar uzanmaktadır. Bu üç güzergahın birleştiği nokta Edirne'dir. Edirne-İstanbul arası hem orta kol menzil yolu olması hem de Osmanlı padişahlarının sık kullandığı bir güzergah olması sebebiyle her daim bakımlıdır. Hem seferler, hem ticaret hem de padişahların kullanmasından dolayı da İstanbul-Edirne aras1 "Sultan Yolu/İstanbul Yolu" ve "Uluyol" gibi isimlerle anılmaktaydı. İşte Bergos söz konusu yol güzergahının tam ortasında yer almaktayd1. ${ }^{9}$ Osmanlı'nın İstanbul'un fethinden itibaren batı güzergahına yapılan seferlerin tamamı Bergos menzilinden geçerek Edirne'ye ulaşmaktaydı. Bergos, ordunun veya ulakların bir konaklama noktası olarak kendisine tahsis edilen nefer ve beygirlerle hizmet vermekteydi. Bergos'un menzil masrafları ise avârız karşıllğında menzilkeş tayin olunan Geyik, Mir-ali, Oklağulu, Kara Musalu, Mesitli, Evrenseki köylerinden karşılanmaktaydı. Hatta seferlerin yoğunlaştı̆̆ yıllarda Bergos menziline destek olarak Havass-1 Mahmud Paşa, Vize, Hayrabolu ve Pınarhisarı kazalarından da gelir aktarılmıştır. Bunlar da yetmediği takdirde ise başkaca köyler ve Tekfurdağı gümrüğünden bir miktar nakit havale olunduğu

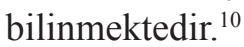

Osmanlı'nın Balkanlara ve Orta Avrupa'ya doğru yayılması ile Rumeli orta

6370 Numaralı Muhasebe-i Vilayet-i Rum-ili Defteri (937/1530), Ankara, Devlet Arşivleri Genel Müdürlüğü, 2001, s. 29, 47; Rumeli Eyaleti (1514-1550), Ankara, Devlet Arşivleri Genel Müdürlüğü, 2013, s. 28.

7 Ömer Lütfi Barkan, “Türkiye'de İmparatorluk Devirlerinin Nüfus ve Arazi Tahrirleri ve Hakana Mahsus İstatistik Defterleri (II), İstanbul Üniversitesi İktisat Fakültesi Mecmuası, c. II/2, İstanbul, 1941, s. 235.

8 Orhan Kılıç, "Batı Karadeniz Kıyısında Bir Osmanlı Eyaleti: Özi/Silistre (İdari Taksimat ve Yönetim)”, Karadeniz Incelemeleri Dergisi, say1 23, 2017, s. 39-42.

9 Fatih Müderrisoğlu, "Menzil Kavramı ve Osmanlı Devletinde Menzil Yerleşimleri”, Türkler, ed. Hasan Celal Güzel, Kemal Çiçek, Salim Koca, c. X, Ankara, Yeni Türkiye Yayınları, 2002, s. 921.

10 Sema Altunan, "XVII. Yüzyıl Sonlarında İstanbul-Edirne Arasındaki Menziller ve Bazı Menzilkeş Köyler”, Tarih Araştırmaları Dergisi, c. 25, sayı 39, Ankara, 2006, s. 85-87. 
kolunun önemi artmış, bu durum güzergah üzerinde yer alan Bergos'u olumlu yönde etkilemiştir. Özellikle Sokullu Mehmed Paşa döneminde burada geniş çapta bir imar faaliyeti olmuştur. Hatta Sokullu Mehmed Paşa, Bergos'ta kendi adını taşıyan bir külliye inşa ettirmiştir. Külliye içinde cami, medrese, sıbyan mektebi, imaret, kervansaray, hamam, köprü ve dükkanlar bulunmaktaydı. Külliyeye Sokullu Mehmed Paşa zamanında su da getirilmiş ve Sultan II. Selim'in ikameti için bir de saray yaptırılmıştır. ${ }^{11}$

Karlofça antlaşması ile birlikte üç cephede devam eden savaş sona ermişti ancak Osmanlı Devleti'nde büyük toprak kayıplarının yanında idarî, askerî, malî ve içtimaî alanlarda nizam bozulmuş ve asayiş kalmamıştı. Uzun süren savaşlar sebebiyle artan vergi ve başkaca mükellefiyetler sebebiyle köylüler toprağını terk ederek şehir ve kasabalara göç etmişti. İşte XVIII. yüzyılın başları Osmanlı Devleti'nin bir çok alanda yeniden toparlanma döneminin başlangıcı olarak dikkat çekmektedir. Bir tarafta hudutlarda tahkimat faaliyetleri diğer tarafta asker sayısının azaltılması yanında vergilerin düşürülmesi ile halkın rahatlatılmasının amaçlanması bunlardan bazılarıdır. ${ }^{12}$ Ülke genelinde her alanda başlayan söz konusu yeniden yapılanma faaliyetlerinin vergiye tabi nüfusu tespit için sayımların da yapılmasını zaruri kıldığı aşikardır. Sancak merkezi olması hasebiyle Vize'nin geçmiş dönemlerde tahrir ve avârız sayımları yanında demografik ve selatin vakıfları hakkında çalışmalar yapılmıştır. Ancak bunlar içinde Bergos kazası için yapılan hususî bir çalışma bulunmamaktadır. Hatta 1642 tarihli Avârız Deferine göre Vize kazaları ele alınırken Bergos'un söz konusu defterde yer almaması dikkat çekici bir durumdur. ${ }^{13}$

Bu çalışmada Bergos kazasında 1712 yılında yapılan tahririn ahalinin şikayeti üzerine tekrarlanması ile gerçekleştirilen "Mufassal-İcmal Avârız Defteri" konu edilmektedir. Söz konusu defter Kamil Kepeci Tasnifi içerisinde Genel No 2840 ve Özel No 294 olarak kayıtlı bulunmaktadır. Defterin tamamı Vize sanca-

11 Gülçin Küçükkaya, "Mimar Sinan Dönemi İstanbul-Belgrad Arası Menzil Yapıları Hakkında Bir Deneme", Vakıflar Dergisi, sayı 21, Ankara, 1990, s. 185; Fatih Müderrisoğlu, "Osmanlı İmparatorluğunda Menzil Yolları ve Menzil Külliyeleri”, Osmanll, ed. Güler Eren, c. 10, Ankara, Yeni Türkiye Yayınları, 2002, s. 381-382.

12 İsmail Hakkı Uzunçarş11, Osmanlı Tarihi, c. IV, Ankara, Türk Tarih Kurumu, 1983, s. 1-7.

13 Volkan Ertürk, "1642 Tarihli Avârız Defterlerine Göre Vize Sancağı Kazaları”, EKEV Akademi Dergisi, yı1 17, sayı 57, Güz 2013, s. 209232-. Bunun dışında Bergos kazasının bağlı olduğu Vize sancağı ile ilgili yapılan bazı çalışmalar mevcuttur. Bunlar; Mehtap Özdeğer, “16. Yüzyılda Vize Sancağının Demografik ve Ekonomik Yapısı”, Türk Dünyası Araştırmaları Dergisi, sayı 132, Haziran 2001, s. 87-123; Güler Yarcı, “Arşiv Belgeleri Işı̆̆ında Vize (XVIII.-XX. yy), Vize II. Tarih ve Kültür Sempozyumu, 10 Haziran 2005, s. 160-248. 
ğına bağlı Bergos kazasının mahalle ve köylerinin tahririnden oluşmakta ve tipik "mufassal-icmal defteri" şeklindedir. Defterdeki kayıtlar dikkate alınarak Bergos kazasının 1712 yılındaki avârızhâneleri, mahalle ve köylerinin demografik ve sosyal yapısı ortaya çıkarılmaya çalışılmıştır.

\section{Osmanlı İmparatorluğu'nda Avârız Tahrirleri}

Osmanlı İmparatorluğu'nda vergi mükelleflerini tespit amaciyla ülke genelinde muhtelif zamanlarda sayımlar yapılmaktaydı. Söz konusu sayımlara "tahrîr" ve bunların kaydedildiği defterlere de "Tahrîr Defterleri" adı verilmekteydi. Klasik dönemde tahrirlerin periyodik bir tarih aralığı olmamakla birlikte 30 yılda bir yapıldığı genel kabul görmektedir. Tahrirler genellikle yeni fethedilen bölgelerde ve saltanat değişimlerinde XV. ve XVI. yüzyıl boyunca yapılmış ve XVII. yüzyıl başlarına kadar devam etmiştir. ${ }^{14}$ Osmanlı Devleti, söz konusu tahrirler sayesinde ülkenin muhtelif gelir kaynaklarını, nüfus ve arazi durumundaki değişimleri sağl1klı bir şekilde takip ve tespit imkanına haiz oluyordu. ${ }^{15}$ Gelir kaynaklarının ülke genelinde dağılımı tahrirler sayesinde belirleniyordu. Osmanlı maliyesinin klasik döneminde gelir kaynakları üç ana kalemden oluşmaktadır. Bunlar mukataa, cizye ve avârızdır. Mukataa gelirleri özel şahıslarca işletilen kamu iktisadi ve mali kurumları olup bütçe içindeki oranı \% 24-37 arasında değişmekteydi. Cizye gelirleri ise Müslüman olmayan faal erkek nüfustan alınmaktaydı. Bunun bütçe içindeki oranı ise \% 23-48 arasında değişiklik göstermekteydi. Avârız gelirleri ise "tekâlif-i örfiyye" veya "avârız-ı divâniyye" denilen olağandışı vergilerdir. ${ }^{16}$

Avârız, Osmanlı İmparatorluğu'nda olağanüstü hallerde ve özellikle sefer masraflarını karşılamak için sultanın emri ile halkın doğrudan doğruya devlete vermek zorunda olduğu her hürlü hizmet, eşya ve para mükellefiyetlerini ihtiva etmektedir. Avârız vergilerinin kapsamı çok genişti. Askerin geçeceği yolları açmak, zahire tedarik etmek, savaş malzemesi hazırlamak, araba ve hayvan temini, "avârız akçesi" adıyla sefer masraflarına iştirak etmek bu verginin başlıcaları idi. ${ }^{17} \mathrm{Bu}$ kadar çeşitli ve kapsamlı bir vergi olan avârızın olağan hale gelmesinin temelinde XVI. yüzyılın sonlarına doğru Osmanlı İmparatorluğu'nda mey-

14 Mehmet Öz, "Tahrir", TDVIA, c. 39, İstanbul, 2010, s. 425-426.

15 Ömer Lütfi Barkan, “Türkiye'de İmparatorluk Devirlerinin Büyük Nüfus ve Arazi Tahrirleri ve Hakana Mahsus İstatistik Defterleri (I)", İstanbul Üniversitesi İktisat Fakültesi Mecmuasl, c. III/I, İstanbul, 1941, s. 25.

16 Ahmet Tabakoğlu, "Klasik Dönemde Osmanlı Ekonomisi", Türkler, ed. Hasan Celal Güzel, Kemal Çiçek, Salim Koca, c. 10, Ankara, Yeni Türkiye Yayınları, 2002, s. 671-672.

17 Ömer Lütfi Barkan, “Avârız”, İslam Ansiklopedisi (İA), c. 2, İstanbul, Milli Eğitim Basımevi, 1979, s. 13-14. 
dana gelen büyük değişimlerin mali sistemi de derinden etkilemesi gelmektedir. Yine aynı dönemlerde devlet artık çok geniş sınırlara ulaşmış, savaşlar eskisi gibi gelirleri arttırma yerine büyük masraflara sebep olmaya başlamıştı. Ekonomik dengelerin gittikçe bozulması, Anadolu'da eşkıyalığı arttırmış, köylü toprağını terk etmiş, buna Akdeniz havzasında normalin üstünde gerçekleşen nüfus artış1 da eklenmiştir. Bütün bunlara yüzyılın sonunda başlayıp bir türlü sonuçlanmayan savaşların yıpratıcı etkisi de dikkate alındığında devletin finansman için bulduğu en önemli kaynak avârız vergilerinin devamlı hale getirilip arttırılması olmuştu. Geçmişte sadece sefer zamanlarında tahsil edilen avârız vergileri zamanla her yıl alınan nakdî bir vergi haline gelmiş ve miktarı da sürekli arttırılmıştır. Avârız doğrudan hazineye giren bir vergi olduğu için devletin gelirlerini arttırmak için tercih ettiği kolay bir seçenek olmuştur. ${ }^{18}$ XVI. yüzyıl sonuna doğru devlet maliyesi için gittikçe ehemmiyet kazanmaya başlayan avârız grubu vergiler 1620-1621 yılından itibaren her yıl düzenli olarak toplanan yıllık vergi haline gelmiştir. ${ }^{19}$

Osmanlı İmparatorluğu'nda yetişkin erkek nüfus tahrir edildikten sonra avârız vergisine esas olmak üzere bir takım vergi birimlerine ayrılırdı. Klasik tahrirlerde sancaklar esas alınırken avârız tahrirlerinde kazalar esas alınmaktaydı. Eyaletlerdeki kazalara göre tespit edilen bu vergi birimlerine "avârız hânesi" denilirdi. XV. ve XVI. yüzyıllarda bir avârız hânesi bir gerçek hâneye tekabül ederken XVII. yüzyılda birden fazla gerçek hâneye tekabül etmeye başlamıştır. Avârız hâneleri tespit edilirken mınıtka zenginliği, ahalinin şehirli, köylü, göçebe olması, dükkan, ev, tarla miktarı gibi bir takım kriterler dikkate alınırd1. ${ }^{20}$ Avârız hânesi; sayısı bölgeden bölgeye değişmekle birlikte gerçek bir hâne olmayıp itibarî bir hâneyi ifade etmektedir. Bir avârız hânesinde yerine göre bazen 3, bazen 5, bazen 10 gerçek hâne bulunabilirdi. Her mahalle veya köyün nüfusu deftere kaydedildikten sonra söz konusu nüfusun kaç avârız hânesi kabul edileceği tespit edilirdi. Bu nedenle bazı mahalle ve köylerin avârız hâneleri buçuk $(0,5)$, rubu'( 1/4) veya sülüs (1/3) şeklinde kesirli de olabilirdi. Devlet, mahalle ve köylerin avârız hânelerini tespit ettikten sonra her bölgenin kadısına hükümler gön-

18 Halil İnalcık, Devlet-i Aliyye, Osmanlı İmparatorluğu Üzerine Araştırmalar-I, Klasik Dönem (1302-1606), İstanbul, Türkiye İş Bankası Kültür Yayınları, 2009, s. 191-195.

19 Özer Küpeli, "Klasik Tahrirden Avârız Tahririne Geçiş Sürecinde Tipik Bir Örnek: 1604 Tarihli Manyas Avârız Defteri”, CIÉPO Osmanlı Öncesi ve Osmanlı Araştırmaları Uluslararası Komitesi XVII. Sempozyumu Bildirileri (Trabzon, 18-23 Eylül 2006), haz. Kenan İnan, Yücel Dursun, Trabzon, Karadeniz Araştırmaları Enstitüsü Yayınları, 2011, s. 510.

20 Enver Çakar, “17. Yüzyılın İkinci Yarısında Antakya Kazâsında İskân ve Nüfus (1678/1089 tarihli Avârız-hâne Defterine Göre)”, Belleten, c. LXVIII, sayı 252, Ağustos 2004, s. 433434-. 
dererek avârız-1 divaniyyenin tahsilini emrederdi. ${ }^{21}$ Başlangıçta ihtiyaca binaen ve düzensiz olarak toplanan avârız vergileri, XVII. yüzyıl başından itibaren tahsil periyodundan başka değişiklikler de yapılmıştır. Bilindiği üzere avârız vergisinde başta askerî sınıflar olmak üzere muafiyet tanınmış kişi ya da gruplar mevcuttu. Yeni düzenleme ile birlikte ilk etapta avârız vergisinden muaf grupların sayısı mümkün mertebe azaltılmaya çalışılmış, "emlak ve arazi sahibi" olan herkes vergi mükellefi haline getirilerek bu konuda reaya ve askerî ayrımı yapılmamıştır. Yine yapılan diğer bir değişiklik nakdî, aynî veya hizmet olarak eda edilen bu vergi, avârızın temeli olan gerçek hâneden iki veya daha çok gecçek hâneyi içeren itibarî avârız hânesine geçilmiştir. Böylelikle tahsil edilecek vergi miktarı ahalinin ödeme güçlerine göre dönemlere ve bölgelere göre değişen belli sayıdaki gerçek hânelerden yola çıkarak tespit olunan bu avârız hâneleri üzerinden toplanmıştır. Nüfusta yaşanan değişimlerden dolayı avârız hânelerinin güncellenmesi gerekmiş ve bu amaçla çoğunlukla bölgesel olmakla birlikte bazen de imparatorluk çapında sayımlar gerçekleştirilmiştir. ${ }^{22}$

Osmanlı İmparatorluğu'nda ilk avârız tahrirlerinin XVII. yüzyıl başlarında yapıldığı son zamanlarda yapılan araştırmalarda tespit edilmiştir. Buna göre bir taraftan klasik tahrirler tedricî olarak terk edilirken bunun yerini devlet bütçesinde gittikçe önemli meblağlara ulaşan avârız vergilerini tahsil amaciyla "avârız" tahrirler yapılmaya başlandığ 1 anlaşılmaktadır. ${ }^{23}$ Osmanlı tarihinde avârız tahrirlerinin en geniş anlamda yapıldığ iki tarih dikkat çekmektedir. Bunlardan ilki Sultan İbrahim döneminde 1640-1642 yılları civarında Kemankeş Kara Mustafa Paşa tarafından Anadolu ve Rumeli'de yapılan tahrirlerdir. ${ }^{24}$ Söz konusu tahrir-

21 Barkan, "Avârız”, s. 15.

22 Oktay Özel, “Avârız ve Cizye Defterleri”, Osmanlı Devleti’nde Bilgi ve İstatistik, der. Halil İnalcık, Şevket Pamuk, Ankara, Başbakanlık Devlet İstatistik Enstitüsü, 2000, s. 38-39; Osmanlı'da raiyyet vergilerinden muafiyet için bk. Halil İnalcık, "Osmanlı'da Raiyyet Rüsûmu”, Belleten, c. XXXIII, say1 92, 1959, s. 595-601.

23 XVI. yüzyıl sonlarında avârız sayımları yapılmakla birlikte bunlarda avârız ve cizye yükümlülüklerinin birlikte kaydedildiği görülmektedir. Müstakil avârız defterlerinin ilk örneği 16001601 yıllarına aittir. Öz, “Tahrîr”, s. 428-429; Yine Manyas Mufassal Avârız Defteri 1603-1604 yıllarına ait olup, mufassal avârız tahrir defterlerinin ilk örneklerinden biri olma özelliğine sahiptir. Küpeli, a.g.m., s. 512.

24 Eren Bahri Gök, "89 Numaralı Mühimme Defteri”, (Yayımlanmamış Yüksek Lisans Tezi), Marmara Üniversitesi Türkiyat Araştırmaları Enstitüsü, İstanbul, 2003, s. 67, 107-108, 111, 167, ; Topçular Katibi Abdülkâdir (Kadrî) Efendi Tarihi (Metin ve Tahlîl), c. II, haz. Ziya Yılmazer, Ankara, Türk Tarih Kurumu, 2003, s. 1149; Söz konusu dönem ile ilgili çok sayıda çalışma mevcuttur. Bunlardan bazıları şunlardır: Mehmet İnbaş1, 17. Yüzyıl Kayseri Avârız ve Cizye Defterleri, Kayseri, Kayseri Büyükşehir Belediyesi Kültür Yayınları, 2011, aynı yazar 
lerin bu yıllar ile sınırlı kalmayıp bazı kazalardan gelen talepler veya daha önce yapılan tahrirlere ahalinin itirazları üzerine 1650 yılına kadar devam ettiği görülmektedir. ${ }^{25}$ Bunlardan başka yine uzun ve yıpratıcı savaş dönemlerinin bitmesi ve imparatorluğun sınırlarının değişmesi sebebiyle demografik yapının ölüm ve göçlerle büyük ölçüde değiştiği bilinmektedir. Söz konusu değişiklikler ahali üzerindeki mükellefiyetlerin yeniden tanzimini gerektiren bir durumdur. Nitekim XVIII. yüzyılın başlarında ülke genelinde yeni tahrirler yapıldığını gösteren bir çok örnek mevcuttur. Bunların tarihleri dikkate alınarak 1708-1710 yılları arasında genel tahrirler yapıldığ 1 anlaşılmaktadır. ${ }^{26}$ Ancak Osmanlı arşivindeki avârız tahrir kayıtlarında görüldüğü kadarıyla genel sayımlar haricinde devlet, muhtelif tarihlerde ihtiyaç üzerine veya talep halinde sayımlar yaptırarak vergi mükelleflerini daima güncel olarak takip etmeye çalışmıştır. Nitekim Karinabad kazasında 1646, 1678 ve 1729 yıllarında yapılan avârız tahrirleri bunun açı örneklerini teşkil etmektedir. ${ }^{27}$

Avârız defterleri klasik tahrirlerde olduğu gibi mufassal ve icmal olarak tertip edilmiştir. Mufassal avârız defterlerinde kaza, kazaya bağlı köyler, kırsal yerleşimler dahil olmak üzere vergi mükellefi olan Müslüman ve gayr-i müslim reaya, arazi ve emlak tasarrufunda bulunan askerî sınıflar tespit edildikten sonra muafiyetler dikkate alınarak itibarî avârızhâne sayısı belirlenirdi. XVII. ve XVIII. yüzyılda nüfus ve iskan yapısını tespite yarayan çok sayıda mufassal avârız def-

“1642 Tarihli Avârız Defterine Erzurum Şehri”, Türk Kültürü Incelemeleri Dergisi, sayı 4, İstanbul, 2001, s. 9-32; Eyüp Kul, "1642 Tarihli Avârız Defterine Göre Şiran Kazası ve Köyleri”, Atatürk Üniversitesi Türkiyat Araştırmaları Dergisi, sayı 44, Erzurum, 2010, s. 271-289.

25 Oktay Özel, "17. Yüzyıl Osmanlı Demografi ve İskan Tarihi İçin Önemli Bir Kaynak: "Mufassal Avârız Defterleri”, XII. Türk Tarih Kongresi, (12-16 Eylül 1994), Kongreye Sunulan Bildiriler, c. III, Ankara, 1994, s. 739; Mehmet Ali Ünal, “1646 (1056) Tarihli Harput Kazâs1 Avârız Defteri”, Tarih Incelemeleri Dergisi, c. XII, İzmir, 1997, s. 12-13.

26 Lütfi Güçer, XVI.-XVII. Asırlarda Osmanlı Imparatorluğunda Hububat Meselesi ve Hububattan Alınan Vergiler, İstanbul, İstanbul Üniversitesi İktisat Fakültesi, 1964, s. 7072-; Turan Gökçe, "Osmanlı Nüfus ve İskan Kaynaklarından "Mufassal-İcmal" Avârız Defterleri ve 1701-1709 Tarihli Gümülcine Kazâs1 Örnekleri”, Tarih İncelemeleri Dergisi, c. XX/I, Temmuz 2005, s. 83-87; XVII. yüzyıldan XVIII. yüzyıl başlarına kadar bunların dışında avârız sayımlar1 ile ilgili yine çok sayıda araştırma yapılmıştır. Bunlardan bazıları şunlardır: Mustafa Öztürk, “1675-1676 (h. 1086) Şam Avârızhâne Defteri”, Fırat Üniversitesi Orta Doğu Araştırmaları Dergisi, c. II, sayı 2, Elazı̆̆, 2004, s. 75-93; Turan Gökçe, "Bir Tahrir Üç Defter: 1697-1698 Avârız Defterlerine Göre Siroz (Serez) Şehri”, Türk Dünyası Incelemeleri Dergisi, cilt VI, say1 1, İzmir, 2006, s. 51-73; Münir Aktepe, "XVII. Asra Ait İstanbul Kazâsı Avârız Defteri”, İstanbul Enstitüsü Dergisi-III, İstanbul, 1957, s. 109-139.

27 Musa Sezer, “Avârız Kayıtlarına Göre XVII. ve XVIII. Yüzyıllarda Karinabad Kazâsı”, History Studies, c. 10, say1 9, Aral1k, 2018, s. 301-302. 
teri mevcuttur. Avârız defterlerinin diğer bir türü de icmal avârız defterleridir ki, eyaletlere bağlı sancaklarda bulunan kazaların avârız hâneleri mevcuttu. Söz konusu defterler de kaza ve köylerin nefer sayısı ve bunların avârız hânelerinden müteşekkildi. Gerek klasik dönem tahrir defterleri ve gerekse avârız tahrirleri için tutulan defterler "mufassal" ve "icmal" şeklinde iki tür olarak ele alınmıştır. Bunlara ilave olarak üçüncü bir tür mufassal ve icmal kayıtlarının bir arada tutulduğu avârız defterleri de mevcuttur ki bunlara "Mufassal-İcmâl" şeklinde adlandırma yapılmaktadır. Bu defter türünün Osmanlı merkez bürokrasisinde kullanım pratikliği amacıyla hazırlandığı tahmin edilmektedir. Söz konusu defterlerin icmal kısmında öncelikle kazaya bağlı köy ve mahallelerin isimleri, nefer sayıları, çiftlik sayıları ve avârız hâneleri verilmektedir. Bundan sonra gelen mufassal kısmında ise kaza dahilindeki köy ve mahallelerin nefer isimleri, görevleri, lakapları, meslekleri, özürlülük durumları, askerler ve bunların bölük ve yevmiyeleri, seyyit, imam, dul, yetim, çocuk vb. özellikleri, çiftlik isimleri kaydedilmiştir. ${ }^{28}$

\section{Tarihli Bergos Avârız Defteri}

Osmanlı Arşivinde Kamil Kepeci kataloğunda yer alan 2840 numaralı 1712 tarihli Bergos Kazası Avârız Defteri, bu çalışmanın ana kaynağıdır. Defterde yer aldığ 1 üzere 1712 yılında yapılan tahririn sebebi Bergos kadıs1 ve kazada bulunan diğer ümeraya gönderilen hükümde açıkça izah edilmektedir. Söz konusu hükümde belirtildiğine göre Bergos kazasının ahalisi bir müddet önce yapılan tahrirden dolayı kazalarında bulunan Evlad-1 Fatihân için "üzerlerine muharrir olunan hâneyi vermeğe iktidarları yoktur" diyerek divan-1 hümayuna arzuhal göndermişlerdir. Bu itiraz üzerine Bergos kazasına yeniden tahrir için bir muharrir ve katip tayin olunmuştur. ${ }^{29}$ Osmanlı Devleti'nde tahrir eminleri öteden beri işinin ehli ve kendisine itimat edilen kimselerden tayin edilirdi. Tahrir eminlerinin dikkat edeceği mühim noktalardan biri yeni tahrirlerin eskisinden noksan olmamasına gayret etmektir. Ancak devletin her zaman gelirlerini arttırmak hedefi bazen ahali üzerinde büyük baskı ve suistimallere sebep olmaktaydı. Özellikle gerileme döneminde yönetim ve maliyenin bozulmaya başladığı devirlerde tahrir işi adeta müzayede ile fazla gelir tutturmaya taahhüt eden mültezim eminlerinin

28 Öz, "Tahrir", s. 429; Gökçe, a.g.m, s. 75-81; Feridun M. Emecen, "Mufassaldan İcmale”, Osmanlı Araştırmaları, sayı XVI, İstanbul, 1996, s. 40; Çift veya çiftlik arazinin verim durumuna ve bölgelere göre değişmekle birlikte 60 ilâ 150 dönüm arasındaki topraklardır. Mesela Konya'da çiftlik eğer verimi çok iyi ise 60 dönüm, orta düzeyde ise 80-90 dönüm ve daha düşük ise 100-120 dönüm topraklardan teşekkül ederdi. Ancak bu miktar Rumeli'de daha farklıdır. Bkz. İnalc1k, a.g.m., s. 581-582.

$29 K K . d$., nr. 2840, s. 17. 
uhdesine geçmiştir. Yine kimi zaman okuma yazma dahi bilmeyen kimselerin tahrir ile görevlendirildiği görülmektedir. Bunlar bir taraftan taahhüt ettikleri gelir fazlasını çıkarmaya çalışırken diğer taraftan ahaliye zulmetmekte ve bu durum şikayetlere konu olmaktadır. ${ }^{30}$ Nitekim benzer bir durum 1712 yilında Bergos kazasının avârız tahriri esnasında da yaşanmıştır. Bergos kazası tahriri için tayin olunan görevlilerin "umûr-ı tahrîrden bî-haber" oldukları ve ayrıca "tama '- $i$ hamdan” (aç gözlülük) dolayı kimi köylerde fazla kimi köylerde ise noksan sayım yaptıkları, Sultan Selim Han ve Rüstem Paşa vakıflarına gereğinden fazla hâne yazarlarken diğer taraftan Şehid Mehmed Paşa Vakfı köylerinde çok sayıda gayr-i müslim nüfus olduğu halde buralarda vakıf mütevellisi köylerin gelirlerinden ücretlerini alıp vergiye dahil etmedikleri gibi suistimalleri bildirilmiştir. Ayrıca sayım sonucunda da kaza ahalisi üzerine eski yıllara nispetle imkan ve iktidarlarından çok fazla tekâlif yazılmıştır. Halbuki Bergos kazası Evlad-1 Fatihân da dahil geçmişte yapılan sayımlara göre avârızlarını 81,5 hâne üzerinden ödemekte idi. Ancak 1712 yılında Hasan tarafından yapılan sayımda Bergos kazasının avârızı 260 hâneye çıkarılmış ve öncekine oranla 179 avârız hânesi arttırılmıştır. Eski avârız hânesine göre \% 313 gibi büyük bir artış olmuş ve bu nedenledir ki kaza ahalisi "hânemize merhameten hak ve adl üzere tahrir olunmak..." talebiyle yapılan sayımın tekrarını istemişlerdir. ${ }^{31}$

Osmanlı yönetimi Bergos kazası ahalisinin talebini uygun bulmuş ve yeniden yapılacak tahrir esnasında iki hususa özellikle dikkat edilmesini istemiştir. Bunlardan biri kazada mevcut askerî, evkaf, çiftlik eshabı, maktû vesair reayanın hiçbir ayrım yapılmadan "ale'l-esâmi"'(isim isim sayılarak) yeniden tahrire dahil edilmesidir. Diğer bir konu da özellikle yeni tayin edilecek muharririn " $m u$ ' $t a$ medün aleyh ve dindar ve müstakim” olmasıdır. Çünkü daha önce tahrir yapan görevlinin hem işinin ehli olmaması hem de şahsî zaafları bulunmasından dolayı köylerin avârız hânelerinde yaptığı hatalar reayanın rencide olmasına sebep olmuştu. Bu defa tahrir esnasına gerekli hassasiyetin gösterilmesi amacıyla " $k a z \hat{a}-i$ mezbûre ve kurâsinda ev-be-ev gezüp kazâ-i mezbûrede sâkin ve mütemekkin hâne-güzâr müselmânân ve zimmiyân re'âyâlar başka ve bir hizmet mukâbelesinde avârızdan mu'âf olup hizmetinizin lüzûmu var mıdır yok mudur sihhat üzere

30 Barkan, "Nüfus ve Arazi Tahrirleri-II", s. 226-227.

31 KK.d., nr. 2840, s. 17, (16 Zilhicce 1123/25 Ocak 1712); Harput kazasının 1640'larda avârız hânesi 238,5 olup, göç veya başka sebeplerle nüfusun azalması üzerine bu miktar tekâlifleri ödemekte zorlanan ahali bunun hafifletilmesi ümidiyle yaptıkları müracaat üzerine 16451646 yıllarında yeni bir sayım yapılmıştır. Bu sayımda Harput kazasının avârız hâne sayısı \% 59,6'lık artışla 400 hâne olarak çıkarılmıştır. Ahalinin şikayet ve mürcaatı üzerine 1646 yılında yeninden tahrir yapılmış ve 186,5 hâneye düşürülmüştür. Ünal, a.g.m., s. 12-13. 
görülüp...” şeklinde sıkı tembihatta bulunulmuştur. Bu arada tahrir esnasında tekâliften muaf olanların da yaptıkları hizmetin lüzumunun olup olmadığının kontrolü istenmiştir. Yine yeniçeri, sipah, topçu, cebeci gibi ulufeli askerlerin doğancı, şahinci taifesinin isimleri, yevmiyeleri, bölüklerinin yanında timar ve zeamet tasarruf edenlerin de deftere kaydedilmesi fermanda yer almıştır. Yine öteden beri muaf listesinde yer alan sadât, eimme, hutebâ da dahil ve bunlardan halihazırda "emlak ve arazi" sahibi olanların da topraklarının "avârız topră̆ l" olması hasebiyle deftere kaydı emredilmiştir. ${ }^{32}$

İncelenen 2840 nolu Avârız Defteri toplam 50 sayfa olup 1 ila 9-16 sayfa araları boştur. Defterin "Mufassal-İcmal” türünde hazırlanmış olduğu görülmektedir. Defterin ilk bölümü tahririn icmali niteliğinde olup bu kısım 2-8 sayfaları arasındadır. İcmal kısmının başlangıç kısmında "Der Liva-i Vize, Kazâ-i Bergos be-cihet-i hânehâ-i avârız ve bedel-i nüzül kazâ-i mezbûre an tahrîr-i Ahmed an hulefâ-i Mevküfât el-vâki 'fî̀ 9 Râ. Sene 1124 ve bâ-telhîs ve bâ-fermân-ı âlî" şeklinde kayıt ile başlamaktadır. Bu kayıttan Bergos kazasının Sultan III. Ahmed döneminde 16 Nisan 1712 (9 Rebîülevvel 1124) tarihinde Mevkufat Kalemi halifelerinden Ahmed tarafindan tahrir yapıldığı anlaşılmaktadır. Defterin bu bölümünde Bergos kazasına bağlı mahalleler ve köylerde yaşayan nefer sayıları, çiftlik sayıları ve avârız hânelerinin icmali verilmiştir.

Defterin ikinci bölümü ise 18-50. sayfalar arasındadır. Bu bölümün başlangiç kısminda "Defter-i tahrîrât ı neferât kazâ-i Bergos an tahrîr Ahmed el-hakîr kâtib-i kalem mevkûfât be-ma' rifet-i Hasan Ağa an-gulâm-ı istihdâm ve be-ma 'rifet-i kâdî ve zâbitân ve a yân kazâ-i mezbûre el-vâki 'fî şehr-i Muharremü'l-harâm sene 1124 bâ-telhîs ve bâ fermân-ı âli” şeklinde bir kayıt mecuttur. Söz konusu kayıttan Bergos kazasında Mevkufat Kalemi katibi Ahmed ile birlikte Hasan Ağa, kadı, zabıtân ve ayan tarafından 1124 yılının Muharrem ayında (Şubat-Mart 1712) mufassal tahrir gerçekleştirildiği anlaşılmaktadır. Bu bölümde ise Bergos kazasının köylerinde ve mahallelerinde yaşayan kişilerin isimleri, meslekleri, görevleri, varsa özür durumları (a'mâ, felçli, ihtiyar, yaralı vs.), yerlerinde olup-olmadıkları, çiftlik sayıları, yevmiyeleri ve avârız hâneleri yer almaktadır. Köy ve mahallelerin tahriri tamamlandığında nefer, çiftlik ve avârız hânelerinin yekûnü verilmektedir. Buradan yola çıkarak denilebilir ki 1712 yılı başlarında (Şubat-Mart) Bergos kazasının mahalle ve köylerinin tahriri yapılmış, akabinden yapılan tahrir önce mufassal olarak sonra da icmal olarak avârız defterine kaydedilmiştir.

32 "kasaba ve kurâda sâkin ve mütemekkin hânekeş re'âyâ ve hizmet mukâbelesinde mu 'âf ve gayr-i mu 'âf ve askerî ve çiftlikân ashâbı ve evkâf ve maktû' 're'âyâlarından bir ferd kalmamak üzere ale'l-esâmi mücededen tahrîr ve defter olunmak üzere...”, KK.d., nr. 2840, s. 17, (16 Zilhicce 1123/25 Ocak 1712). 
Mufassal tahririn deftere kaydı yapılırken hesaplamaya esas teşkil eden nüfus ismen kaydedilmiştir. Muaf veya gayr-i muaf, zimmi veya Müslüman gibi ayrımlar bulunmamaktadır. Bazı mahalle ve köylerde Müslüman ve gayr-i müslimler bulunmasına rağmen bunların bazen zimmi olduğu belirtilmiştir. Bununla birlikte çok defa bunların zimmi olduğunu isimlerinden çıkarabilmek mümkün olmaktadır. Askerî sınıfa mensup olanların görevleri ve bölükleri, aldıkları yevmiyeler veya emekli olanlar da ulufelerini aldıkları yerler belirtilmiştir. Yine tahrirde askerî ve devlet görevlilerinden sayılan imam, hatip, müezzin, katip, cüzhan $^{33}$ ve duahan yazılmışıtır. Bunun yanında seyyit, fakir, yaşlı, felçli, yaralı, a'mâ, yetim, sabi ve dul olanların da bu durumları kaydedilmiştir. Çiftlik sahibi olanların çift miktarı, firar edenler, çiftliği boş ve harabe olanların da kayıtları yer almaktadır. Mahalle veya köyün tahriri tamamlandıktan sonra yekün olarak nefer sayısı, çiftlik adedi ve çift miktarı verilmektedir. Kimi yerde bazen köy, mahalle veya cemaat bazen de kişilerle ilgili notlar defterin muhtevasının anlaşılması açısından kıymeti haizdir.

1712 y1lında fermanda belirlenen prensiplere uygun olarak Bergos kazasının tahriri tamamlanmıştır. Öncelikle mufassal tahrir yapılmış, akabinde avârızdan muaf olanlar düşüldükten sonra vergiye tabi nüfus icmal deferine kaydedilmiştir. İcmal defterinde tahrir sonucu Bergos kazasının avârız hânesi 200,5 rubu' 1,5 olduğu ancak Karışdıran-1 Kebir ve Karışdıran-1 Sağir köylerinin gelirleri maktû olarak tahsil edildiğinden ve henüz avârıza tabi olmadığından bu iki köyün 8 hâne olan avârızhânesi düşülerek 192,5 hâne 1,5 rubu' olarak tespit edilmiştir. Böylelikle bir önceki tahrirde itiraz konusu olan 260 hâneden 67,5 hâne (\% 36) düşüş gerçekleşmiş ve ahalinin talebinde haklı olduğu ortaya çıkmıştır.

\section{Bergos Kazası Mahalleleri}

Kanûnî Sultan Süleyman döneminde 1530 yılında yapılan bir sayıma göre Bergos nahiye olup, 13 köy ve 162 hâneye sahipti. Küçük bir nahiye olduğu için bu tarihlerde merkezde henüz bir mahallesi bulunmamaktayd. ${ }^{34}$ XVI. yüzy1lda yapılan başka bir sayımda ise kaza merkezinde 4 mahalle bulunuyordu. Bunlar; Cami-i Şerif, Tekke-i Hızır, Köhne Cami ve Cedid diğer adıyla Tâye Yusuf

33 Kur'an-1 Kerim cüzlerini okumakla görevli kimselere cüzhan denilmektedir. Cüzhanlar belirli vakitlerde toplanıp birer Kur'an-1 Kerim cüzü okuyarak hatim yapılmış olurdu. Hacı Ahmet Arslantürk, “Bir Bürokrat ve Yatırımcı Olarak Kanûnî Sultan Süleyman'ın Veziriazamı Rüstem Paşa”, (Yayımlanmamış Doktora Tezi), Marmara Üniversitesi Sosyal Bilimler Enstitüsü, İstanbul, 2011, s. 145.

3430 Numaralı Muhasebe-i Vilayet-i Rûm-ili Defteri (937/1530)-I, Ankara, Devlet Arşivleri Genel Müdürlüğü Yayınları, 2001, s. 68. 
mahalleleri idi. Söz konusu mahallelerde 94 hâne ve 7 mücerred olduğu kaydedilmişti. ${ }^{35}$ XVII. yüzyıl ortalarında Evliya Çelebi'nin zikrettiğine göre Bergos kazası, Sokullu Mehmed Paşa evkafindan olup ve mütevvellisi 200 atlısı olan bir hakim idi. Bergos kadısının yevmiyesi 150 akçeydi. Ayrıca kazanın 750 hânesi, adları belirtilmemekle birlikte 6 mahallesi olduğu ifade edilmiştir. ${ }^{36} 1712$ yılına ait 2840 nolu avârız defterinde ise 5 mahalle bulunmaktadır. Bunlar; Mahalle-i Hüseyin Bey, Mahalle-i Cami-i Atik, Mahalle-i Alaca Mescid, Mahalle-i Cedid ve Mahalle-i Rumiyân'dır. Bunlara ilave olarak Mahalle-i Cedid'e bağlı Cemaat-i Kıbtiyân ve Cemaat-i Yahudiyân mevcuttur.

\section{Hüseyin Bey Mahallesi}

1712 yılına ait Bergos Avârız Defteri'ne göre Hüseyin Bey mahallesinde çoğunluğu askerîden olmak üzere 52 nefer mevcuttu. Askerîler arasinda en kalabalık grubu muhtelif bölüklerde görevli silahtarlar oluşturmaktadır. Toplam 16 silahtar olup bunun 5'i emeklidir. Muvazzaf olan silahtarların 20 akçe yevmiyesi olup emekli olanlar ise genellikle Rodosçuk gümrügüunden 2 akçe yevmiye almaktadır. Yine ehl-i örf taifesinden biri odabaşı olmak üzere 5 yeniçeri mevcut olup, odabaşının yevmiyesi 20 akçe diğerlerinin ise 5 akçedir. Ehl-i örf taifesinden bir diğer grup sipahilerdir. Hüseyin Bey mahallesinde biri çavuş olmak üzere 6 sipahi olup, çavuşlarının yevmiyesi 33 akçe diğerleri ise 29 ile 7 akçe arasında değişmektedir. Ehl-i örf taifesinden son olarak iki cebe ve bir topçu bulunmaktadır. Hüseyin Bey mahallesinde Mehmed Paşa Camii ve Hüseyin Bey mescidi mevcuttur. Defterde Şehid Mehmed Paşa Vakfı ve camisinin bazı görevlilerinin olduğu dikkat çekmektedir. Bunlar Şehid Mehmed Paşa Vakfı'nda görevli kâtip ile cami imamı ve beratla görev yapan birer müezzin ve muvakkittir. ${ }^{37}$ Ayrıca "İmâm-ı Sânî Der-Câmi-i Mehmed Paşa Şehîd" ve "An-evvel-i Müezzin-i Câmi-i Şehîd Mehmed Paşa” kayıtlarından hareketle Mehmed Paşa Camii'nde birden fazla imam ve müezzinin görev yaptığı anlaşılmaktadır. Ancak Hüseyin Bey mescidinin sadece bir imamı vardır. Bunlardan başka beratla görev yapan cüzhan ve naathan ${ }^{38}$ da mevcuttu. Burada bulunan imaretin ekmekçisinin de beratla ze-

35 Güler Yarc1, “Osmanlı Yönetiminde Vize Sancağı: Nüfus ve İskan”, IV. Vize Tarih ve Kültür Sempozyити (17-18 Ekim 2008, Vize), Bildiriler, ed. Güler Yarc1, Hüseyin Salman, Vize, 2015, s. 83.

36 Evliya Çelebi b. Derviş Mehmed Z1llî, Evliya Çelebi Seyatnâmesi, 3. Kitap, haz. Seyit Ali Kahraman, Yücel Dağlı, 2. bs., İstanbul, Yapı Kredi Yayınları, 2006, s. 172.

37 Camilerde vakitlerin tayini için saatleri düzenleyen ve bunların ayar ve tamiriyle görevli kimselerdir. Mehmet Zeki Pakalın, Osmanlı Tarih Deyimleri ve Terimleri Sözlüğ̈̈, c. 2, İstanbul, Milli Eğitim Basımevi, 1983, s. 587.

38 Naathan; cami ve tekkelerde naat okuyan görevlilerdir. Pakalın, a.g.e., c. 2, s. 684. 
amet sahibi olduğu, Eski Ahur Kethüdası Osman Ağa'nın 60 akçe yevmiye ile Kırkkilise Koru Ağası ve Saray-ı Cedid kiler kethüdasının da burada olduğu görülmektedir. Hüseyin Bey mahallesinde yaşlı, iş göremez, felçli ve fakir birer kişi dışında iki dul kadın bulunmaktaydı.

\section{Cami-i Atik Mahallesi}

Cami-i Atik mahallesinde yine çoğunluğu askerîden olmak üzere 33 nefer mevcuttu. Askerî sınıf olarak yeniçeri, silahtar, cebe ve cebeci bulunmaktaydı. Yeniçerilerin sadece biri yevmiye almakta diğer ikisinin iş göremez ve mecruh olduğu dikkat çekmekte, silahtarların ikisi de yevmiye almakta, cebe ve cebecilerden ise ikisi yevmiyeli, biri tekaüd ve ikisinin yevmiyesi bulunmamaktadir. Ayrıca birer baltacı serdarı ve korucu mevcut olup, biri hem berat sahibi hem iş göremez evsafta olan iki cüzhan vardı. Bunlardan başka iki dul kadın, birer fakir, özürlü ve deli bulunmaktaydı. Cami-i Atik mahallesinde her ne kadar imam veya müezzin gibi bir dinî görevli defterde bulunmamasına rağmen mahalle camisi imamı için tahsis edilen "meşrûta” nın varlığı da dikkat çeken bir husustur. Yine burada tahrir olunan Lütfi b. Mustafa’nın görevi yazmamakla birlikte Rodosçuk gümrüğünden 2 akçe yevmiye aldığı kayıtlıdır.

\section{Alaca Mescid Mahallesi}

Bergos kazası avârız defteri kayıtlarına göre Mahalle-i Cedid'den sonra en kalabalık mahallesinin Alaca Mescid olduğu dikkat çekmektedir ve 61 nefer ikamet etmektedir. Yine diğer mahallerde olduğu gibi burada da ikamet edenlerin çoğunluğunu askerî sınıf mensupları oluşturmaktadır. Söz konusu askerî sınıflar içinde divan çavuşu, yeniçeri, arabacı, sipah, silahtar ve cebeciler bulunmaktadır. Askerî sınıflar içinde çoğunluğu 7 akçe yevmiyeli muhtelif bölüklere mensup 10 yeniçeri mevcut olup sadece biri tekaüddür. Diğer bir askerî sınıf olan silahtarlar ise 30-14 akçe yevmiyeli 6 neferdir. Bundan başka ikişer neferden 4 nefer sipah ve cebeci ve ayrıca bir arabacı vardır. Dinî görevli olarak Alaca Mescid imamı olup, Cami-i Atik mahallesi müezzininin de burada ikamet ettiği anlaşılmaktadır. Alaca Mescid mahallesinde Mehmed Paşa Vakfına ait cami ve imaretinde istihdam edilen bazı görevliler de mevcuttur. Bunlar Mehmed Paşa Vakfının imaretinde berat ile görevlendirilmiş kilerci, tabbâh, câbi ${ }^{39}$ ve bevvâb olup, ancak bevvâbın iş göremez olduğu kayıtlıdır. Yine Mehmed Paşa Camii’nde görevli

39 Osmanlılar'da vakıfların kira ve gelirlerini toplayan görevli olup Arapça “cebee" kökünden türetilmiştir. Özellikle büyük vakıfların idaresinde yer alır, ücretleri vakfiyelerde belirlenmiş olup, tayin, azil, teftiş gibi idarî ve hukukî işleri vakfın bulunduğu mahallin kadısı tarafından yürütülürdü. Mehmet İpşirli, “Câb̂̂”, TDVİA, c. 6, İstanbul, 1992, s. 529. 
birer muarrif ${ }^{40}$ ve devirhanın ${ }^{41}$ olduğu görülmektedir. Bu görevlilerin dışında üç dul kadın, bir seyyit, iki yetim, iki iş göremez kişi ve birer kasap ve esir mevcuttur. Burada tekaüd sınıfında olan sadece iki kişi olup bunlar Rodosçuk ve İstanbul gümrüğünden ulufelerini almaktadır.

\section{Yeni Mahalle (Mahalle-i Cedid)}

Bergos kazasının en kalabalık mahallesidir ve 82 nefer sayılmıştır. Bergos'un diğer mahallerinde olduğu gibi burada da ehl-i örf denilen sinıf nüfusun kahir ekseriyetini teşkil etmektedir. Bunlar arasında yine en yoğun grup yeniçeri ve silahtarlar olup az da olsa sipah ve cebeci mevcuttur. Mahallede muhtelif bölüklere mensup 20 nefer yeniçerinin ikisi iş göremez ve yaşl1, ikisi tekaüd ve ikisinin de çiftlik sahibi olduğu dikkat çekmekte olup yevmiyeleri de 7 akçedir. Yine biri çavuş olmak üzere 16 nefer silahtar olup, bunlardan sadece biri tekaüd olarak gözükmektedir. Silahtar çavuşunun yevmiyesi 52 akçe, diğerleri ise 37 ila 6 akçe arasında değişmektedir. Diğer bir askerî sınıf olan cebe 12 nefer olup, bunlardan biri Rodosçuk gümrüğü biri de İstanbul İhtisap dairesinden emekli ulufesi almaktadır. Genel olarak yevmiyeleri 7 akçe olup biri çiftlik sahibidir.

Din görevlisi olarak Cami-i Atik’te görevli hatip dışında Mehmed Paşa Camii'nde berat sahibi 2 akçe yevmiyeli beş nefer cüzhan, bir nefer kandilciden başka bir de seyyit bulunmaktadır. Mehmed Paşa Vakfı imaretinde görevli aşçıbaşı, neccar, ekmekçi mevcuttur. Mahalle-i Cedid'de bunların dışında berber, bozacı, simsar, üç çiftlik, korucu ve bostancı da bulunmaktadır. Yine 6 dul kadın, birer yaşl1 ve özürlü, garip ve yetim de kaydedilmiş̧ir.

Tablo-1: Bergos Kazası Müslüman Mahalleler Nüfus Hülasası

\begin{tabular}{|l|l|l|l|l|l|}
\hline Mahalle & Neferen & Askerî & Reaya & $\begin{array}{l}\text { Din/Vakıf } \\
\text { Görevlisi, } \\
\text { Seyyit }\end{array}$ & $\begin{array}{l}\text { Fakir, } \\
\text { Dul, Yetim }\end{array}$ \\
\hline Hüseyin Bey & 52 & 28 & 9 & 10 & 4 \\
\hline Cami-i Atik & 33 & 15 & 9 & 2 & 5 \\
\hline Alaca Mescid & 61 & 31 & 12 & 9 & 5 \\
\hline
\end{tabular}

40 Muarrif; camilerle tekkelerde hayır sahiplerinin adlarını hayırla yad eden maaşlı müezzin ve derviş hakkında kullanılan tabirdir. Arapça bir şeyi tarif eden, etrafı ile anlatan kişi demektir. Pakalın, a.g.e, c. 2, s. 552.

41 Vakıf şartları gereği Cuma ve bayram günleri birbirine devrederek Kur'an-i Kerim okuyan görevlilerdir. Arslantürk, a.g.t., s. 146 


\begin{tabular}{|l|l|l|l|l|l|}
\hline Cedid & 85 & 54 & 8 & 9 & 9 \\
\hline Toplam & $\mathbf{2 3 1}$ & $\mathbf{1 2 8}$ & $\mathbf{3 8}$ & $\mathbf{3 0}$ & $\mathbf{2 3}$ \\
\hline
\end{tabular}

\section{Mahalle-i Rumiyan}

Alaca Mescid mahallesinden ayrılmış olup tamamen zimmiler ikamet etmektedir. Toplam 17 nefer olup üzerlerine tahakkuk eden tekâlif, avârız ve nüzüllerini kendi cemaatleriyle birlikte vermektedirler. Ayrıca müslümanlara mahsus mükellefiyetler talep edilerek rencide edilmemeleri emredilmiştir. Söz konusu 17 neferden biri çakırcı olup ancak iş göremez haldedir. Yine biri 10 akçe diğeri 20 akçe yevmiye ile Mehmed Paşa Vakfı'nda suyolcu olarak görev yapmaktadır. Bunların dışında birer nefer olmak üzere dul kadın, iş göremez, yetim ve fakir zimmi mevcuttur. Zimmi isimlerinin çoğunluğunun ise Dimitri, Nikola, Yorgi, Yanaki, İstaki olduğu dikkat çekmektedir. Avârız vergisinden muaf olan kimseler çıkarıldıktan sonra Rumiyan Mahallesinde 12 nefer ve 3 hâne bulunmaktadır.

\section{Diğer Gruplar: Cemaat-i Kıbtiyân ve Yahudiyân}

Bergos kaza merkezinde yukarıdaki mahallelere ilave olarak "Cemaat-i Kıbtiyân" ve "Cemaat-i Yahudiyân" adiyla iki grup daha "hariç ez-defter" olarak zikr edilmektedir. Kıbtiyân cemaati Alaca Mescid mahallesinden ayrı olarak tahrir edilmiş olup önceki tahrirlerde bulunmadığ "hâriç ez-defter" ibaresinden anlaşılmaktadır. Zira tahrir esnasında mevcut arazi kimseye verilmeyip boş bırakılmış olabildiği gibi gözden kaçmış, unutulmuş veya sonradan buraya göç vb. başka bir sebeple yeni gelmiş önceki tahrirlerde defterde kayd1 olmayan kimseleri izah etmek için bu ibareler kullanılırdı. ${ }^{42}$ Kibtiyân cemaati 22 nefer olup içlerinde askerî sınıftan dört cebe mevcuttur. Ayrıca dört dul kadın ve iki yetim çocuk kayıtlıdır. Söz konusu 22 neferden 17 neferi avârıza tabi

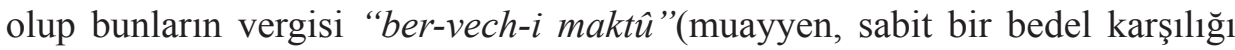
olarak) 3 avârız hânesi olarak kabul edilmiştir. 1712 y1lına kadar Cedid mahallesi ahalisi Kıbtiyân cemaatinden "yardım” adıyla yıllık 4.000 akçe almakta iken bu usulde değişiklik yapılarak artık avârız defterine kaydedilip üç hâne olarak belirlenmiştir. Bundan böyle avârız ve nüzüllerini kendi cemaatiyle eda

$42 K K . d$. , nr. 2840, s. 2; "Hariç-ez defter” denilen yerler çoğunlukla ziraata müsait ancak boş yerlerdir. Böyle yerler ya bir sipahiye verilebilir veya da göçebe grubu buraya gelip kullanmaya başlamış olabilir. Ayrıca iki köy arasında ya da yakınında bulunan boş, kimseye ait olmayan toprağın haymana reaya tarafından açılarak işlenirse bu "hariç ez-defter" olur. Halil İnalcık, Hicrî 835 Tarihli Sûret-i Defter-i Sancak-ı Arvanid, 2. bs, Ankara, Türk Tarih Kurumu, 1987, s. XXV-XXVI. 
edecekleri, Cedid mahallesinden de ayrı tahrir edildikleri için başka bir tekâlif ile rencide edilmemeleri emredilmiştir. ${ }^{43}$

Bergos kazası sakinleri olarak "hariç ez-defter" yazılan diğer bir grup Yahudi cemaati olup ve bunların da ilk defa 1712 yılında yapılan tahrirde kayda geçirildiği anlaşılmaktadır. Bunlar arasında Alaca Mescid mahallesinde çift tasarruf eden "İlya" adlı bir neferden başka "haymana" (başıboş, kayıtsız) olarak da 5 nefer mevcuttur. "Haymana" tabirinden anlaşıldığı üzere bunların göçebe olarak gelmiş veya bulunmuş olmaları kuvvetle muhtemel olup ve önceki defterde kayıtları da yoktur. Söz konusu 6 neferden oluşan Yahudi cemaati de avârız vergisine esas nüfus olarak bir (1) hâne kabul edilmiştir. Yahudi cemaatinin vergisinin

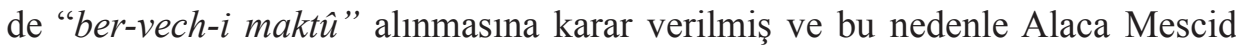
mahallesi ahalisi veya sair kimselerin bunları rencide etmemeleri konusunda şerh verilmiştir. ${ }^{44}$

Tablo-2: Bergos Kazası Mahalleleri Avârız ve Hâne Sayıları (1712)

\begin{tabular}{|l|c|c|c|c|c|}
\hline Mahalle & $\begin{array}{c}\text { Tahrire } \\
\text { Tabi Nüfus }\end{array}$ & $\begin{array}{c}\text { Avârıza } \\
\text { Tabi Nüfus }\end{array}$ & $\begin{array}{c}\text { Avârıza Tabi } \\
\text { Nüfus Oranı }\end{array}$ & Hâne & Rub6 \\
\hline Hüseyin Bey & 52 & 23 & $\% 44,2$ & 5,5 & 1 \\
\hline Cami-i Atik & 33 & 14 & $\% 42,4$ & 3,5 & \\
\hline Alaca Mescid & 61 & 27 & $\% 44,2$ & 7 & 1 \\
\hline Mahalle-i Cedid & 85 & 27 & $\% 31,7$ & 8,5 & \\
\hline Cemaat-i Kibtiyân & 22 & 12 & $\% 54,5$ & 3 & \\
\hline Mahalle-i Rumiyan & 17 & 12 & $\% 70,5$ & 3 & \\
\hline $\begin{array}{l}\text { Cemaat-i Yahu- } \\
\text { diyân }\end{array}$ & $\mathbf{2 7 0}$ & $\mathbf{1 1 5}$ & $\mathbf{\%} 47,9$ & $\mathbf{3 1 , 5}$ & $\mathbf{2}$ \\
\hline Toplam & & & & 1 & \\
\hline
\end{tabular}

Yukarıdaki tabloda görüldüğü üzere Bergos kazası merkezindeki mahalleler ve cemaatlerle birlikte toplam 270 nefer mevcuttur. Bergos köylerinde ise toplam 1029 nefer sayılmıştır. Buna göre nüfusun \% 20,7'si kaza merkezinde, \% 79,3’ü

43 "Bu ana gelince mezbûrlardan Mahalle-i Cedîd ahalisi yardım nâmıyla senede dör bin akçelerin ele gelüp ve hâlâ üç hâne ile maktû' olmaları münâsib ve şerh verilüp fimâ-ba 'd kıbtiyân-ı mezbûrlar üç hâne maktu 'larından gayri tekâlif ile rencîde olunmayup...”, KK.d., nr. 2840, s. 49.

44 "Zikr olunan Yahudi tâ'ifesi haymane olmağla kendü cemâ 'atleriyle ancak ber-vech-i makt $\hat{u}$ ' ve avârız ve nüzüllerin edâ edüp..”, KK.d., nr. 2840, s. 50. 
ise köylerde yaşamaktadır. Kaza merkezinde bulunan 270 neferden muaf, yaşlı, özürlü, çocuk, dul vb. avârıza tabi olmayanlar düşüldükten sonra vergiye tabi nüfus 115 kişi olup toplam nüfusun \% 47,9'nu oluşturmaktadır. Yine Bergos kazası merkez ve köylerinin 1712 yılı avârız miktarı 200,5 hâne 1,5 rubu' olup bunun \% 15,7'sine tekabül eden 31,5 hâne 2 rubu' kadarı merkezde ve \% 84,3'lük kısmını oluşturan 169 hâne 0,5 rubu' kadarı köylerde bulunmaktadır.

\section{Bergos Kazası Köyleri}

1712 yılı avârız defterine göre Bergos kazasına bağlı 44 köy bulunmaktadır. Söz konusu köylerden Misinli diğerlerine göre kalabalık olup buraya Eskeran, Cedid ve Orta olmak üzere 3 mahalle bağlıdır. Bergos kazasının köyleri ya tamamen müslüman ya da tamamen gayr-i müslim nüfustan oluşmaktadır. Kazada bulunan toplam 44 köyden 37'si müslüman, 6's1 ise gayr-i müslim ve sadece Turgutbeyli Köyü'nde müslüman ve gayr-i müslim nüfus birlikte yaşamaktadır. Dikkat çeken bir husus da gayr-i müslim köyleri çok az olmasına rağmen nüfus yoğunluğunun fazla olmasıdır. Nitekim 38 köyde 499 müslüman nüfus mevcut iken 7 köyde 530 gayr-i müslim nüfus bulunmaktadır. Bu sonuca göre Bergos kazası köylerinin \% 48,4'ü müslüman ve \% 51,6's1 ise gayr-i müslimdir. Yine 37 müslüman köyünün \% 62'si 10-20 aras1, \% 27'si 1-10 aras1, \% 11' $i$ ise 20-33 aras1 nüfusa sahiptir. Buna karşıllk 6 gayr-i müslim köyünün nüfusu 38 neferden başlayıp 125 nefere kadar çıkmaktadır. Gayr-i müslim köyleri arasında en az nüfus 38 kişi ile Ahmedbey'de, en kalabalık nüfus ise 125 kişi ile Apullu Köyü’ndedir.

Bergos'un köylerinde yaşayan 1029 neferin 197'si (\% 19,1) askerî, 552'si $(\%$ 53,6) reaya ve 205 'i $(\%$ 19,9) fakir, dul, yetim, yaşl1, özürlü ve 75'i $(\% 7,2)$ toprağını bir şekilde terk etmiş kimselerden oluşmaktadır. Askerî kimseler arasında yeniçeri, cebeci, silahtar, topçu, sipahi, beşe, korucu yanında berat sahibi imam, müezzin, hatip, cüzhan, naathan, seyyit vb. bulunmaktadır. Yine Bergos kazasındaki vakıf ve vakıf kurumlarında berat ile görev yapan kâtip, neccar, aşçı, ekmekçi, câbî, suyolcu, muvakkit, devirhan, bevvâb, muarrif, kandilci, kilerci gibi kimseler olduğu görülmektedir.

Bergos kazası köylerinde farklı meslek sahipleri bulunmaktadır. Müslüman köylerinde meslek gruplarının gayr-i müslimlere göre daha az olduğu görülmektedir. Bunun sebebi olarak müslüman köylerinde nüfusun az olması ve askerî grupların fazla olması düşünülebilir. Müslüman köylerindeki meslekler arasında sığırtmaç, çoban, nalband, dülger, kalyoncu, değirmenci, kaldırımcı ve mandıracı mevcuttur. Gayr-i müslim köylerde görülen meslekler arasında ise değirmenci, terzi, çoban, şahinci, dülger, sığırtmaç, hizmetkar, bahçıvan, sabuncu, muytab (dokumacı), nalband, arabacı, keçeci, kahveci vb. mesleklerin varlığı dikkat çekmektedir. 
Yine Bergos kazası köylerinde dikkat çeken bir husus çok sayıda çiftliklerin mevcudiyetidir. Bu durumu Osmanlı toprak sistemindeki değişim ile izah etmek mümkündür. Nitekim XVI. yüzyıl sonu ve XVII. yüzyıl başlarına doğru Rumeli'de büyük çiftlikler oluşmuştur. Bunların bir kısımını boş ve mirî topraklar üzerinde kurulan çiftlikler oluştururken bir kısmını yine mirî topraklar üzerinde temlik yolu ile kurulmuş vakıf-çiftlikler ve diğer bir kısmını da hazine elinde bulunan boş timar ve has toprakların mukataaya yani özel kişilere kiralanması ile oluşmuştur. Böylelikle Rumeli'de zengin ve nüfuzlu kimseler bir çok köy ve çiftliği kontrolleri altına almışlardır. Şunu da vurgulamak gerekir ki söz konusu toprakları kiralayan kimselerin çoğunluğu askerî sınıf mensuplarıdır. ${ }^{45}$ Bunun temelinde de gerilime dönemi ile birlikte Osmanlı İmpatarorluğu'nda yaşanan iktisadî, askerî ve içtimaî çalkantılar yatmaktadır. Celalî isyanları sebebiyle köylülerin toprağını terk etmesi sonucu bir çok çiftlik askerî zümreler tarafından sahiplenilmiştir. Buraları kendi özel arazileri haline getirerek kölelerini ve kiraladıkları adamlarını yerleştirmişlerdir. İç kargaşadan istifade ederek köylülerin terk ettiği toprakların kullanılması ve mülk haline getirilmesi, reayanın elindeki mirî arazilerin büyük toprak sahiplerinin çiftlikleri haline gelmesinin önü açılmıştır. ${ }^{46}$ İşte Bergos kazasının müslüman köylerinde ve müslüman kimseler uhdesinde olan 111 çiftlik Osmanlı toprak sisteminde XVII. yüzyılda başlayan değişim ve dönüşümün bir sonucudur. Çiftliklerin yoğun olduğu yerler Sayalık, Çengerli, Mir Ali, Müsellem, Karaağaç, Kara Musalu, Evrenseki, Seydiler ve Kayabeyli köyleridir.

Tablo-3: Bergos Kazası Köylerinin Nefer ve Hâne Sayıları (1712)

\begin{tabular}{|l|l|l|l|l|l|l|l|}
\hline Köy & Neferan & $\begin{array}{l}\text { Askerî, } \\
\text { Dinî } \\
\text { Görevliler }\end{array}$ & Reaya & $\begin{array}{l}\text { Fakir, } \\
\text { Yetim, Dul, } \\
\text { İhtiyar vs. }\end{array}$ & Çiftlik & Hâne & Rubu \\
\hline Mukdar & 13 & 5 & 6 & 2 & 2 & 2,5 & 1,5 \\
\hline Sarmusaklı & 8 & 4 & 4 & & 3 & 1 & \\
\hline $\begin{array}{l}\text { Bali-i Hocalı } \\
\text { Kebir }\end{array}$ & 11 & 2 & 6 & 2 & 1 & 1 & 0,5 \\
\hline $\begin{array}{l}\text { Bali-Hocal1-i } \\
\text { Sağir }\end{array}$ & 11 & 4 & 4 & 2 & 1 & 1 & \\
\hline İnanlı & 9 & 6 & 3 & & 2 & 0,5 & \\
\hline
\end{tabular}

45 İnalc1k, Devlet-i Aliyye-I, s. 330-332.

46 Halil İnalcık, "Çiftliklerin Doğuşu: Devlet, Toprak Sahibi ve Kiracılar”, Osmanlı Toprak Mülkiyeti ve Ticarî Tarım, ed. Çağlar Keyder, Faruk Tabak, İstanbul, Tarih Vakfı Yurt Yayınları, 1998, s. 22-23. 


\begin{tabular}{|c|c|c|c|c|c|c|c|}
\hline Sayalık & 29 & 10 & 10 & 6 & 10 & 7,5 & 1 \\
\hline Kara Musalu & 17 & 6 & 6 & 4 & 5 & 5,5 & \\
\hline Evrenseki & 18 & 5 & 7 & 3 & 5 & 1,5 & 1 \\
\hline Taşlı & 14 & 9 & 4 & & 2 & 3,5 & \\
\hline Turgutbeyli & 30 & 5 & 13 & 5 & 3 & 2,5 & \\
\hline Çengerli & 15 & 5 & 7 & 2 & 6 & 6 & 1 \\
\hline Paşa & 11 & 3 & 1 & 1 & 3 & 2 & \\
\hline Pınarbaşı & 6 & & 2 & 4 & 1 & 1,5 & \\
\hline Oklağulu & 16 & 9 & 4 & 2 & 4 & 5,5 & \\
\hline Bedir & 13 & 5 & 3 & 3 & 3 & 4,5 & 1 \\
\hline Kuruca Ali & 5 & 3 & 2 & & 4 & 3 & 1 \\
\hline Mir Ali & 15 & 2 & 6 & 7 & 7 & 6 & 1 \\
\hline Eyneller & 13 & 1 & 7 & 3 & 4 & 4 & \\
\hline Misinli & 60 & & 51 & 4 & 1 & 13,5 & \\
\hline Ahmedbey & 38 & & 28 & 6 & 1 & 8 & \\
\hline Köpeklü & 3 & & 3 & & 3 & 2 & 1 \\
\hline Müsellem & 22 & 11 & 7 & 3 & 6 & 3,5 & 1 \\
\hline $\begin{array}{l}\text { Kara Danış- } \\
\text { mendlü }\end{array}$ & 16 & 8 & 4 & 2 & 2 & 1,5 & 0,5 \\
\hline Düğüncübaşı & 4 & 3 & 1 & & 1 & 2 & 1 \\
\hline Karaağaç & 19 & 10 & 5 & 4 & 2 & 2 & \\
\hline Seydiler & 15 & 7 & 4 & 2 & 5 & 4,5 & \\
\hline Akçaköy & 9 & 2 & 1 & 4 & 1 & 1,5 & \\
\hline Umurca & 17 & 10 & 4 & 1 & 2 & 4 & \\
\hline Çatal & & & & 1 & 1 & 1 & \\
\hline $\begin{array}{l}\text { Yörük-i } \\
\text { Kafir }\end{array}$ & 3 & 2 & & 1 & 1 & 1 & \\
\hline $\begin{array}{l}\text { Sevindik-i } \\
\text { Sağir }\end{array}$ & 18 & 6 & 10 & 2 & 2 & 1 & 0,5 \\
\hline $\begin{array}{l}\text { Sevindik-i } \\
\text { Kebir }\end{array}$ & 13 & 2 & 7 & & 1 & 2 & 1 \\
\hline Kayabeyli & 11 & 3 & 3 & 3 & 5 & 2,5 & 1 \\
\hline Sat1 & & & & & 2 & 1 & 1 \\
\hline
\end{tabular}




\begin{tabular}{|l|l|l|l|l|l|l|l|}
\hline $\begin{array}{l}\text { Karışdıran-1 } \\
\text { Kebir }\end{array}$ & 33 & 18 & 7 & 6 & 1 & 6 & 1 \\
\hline Çiftlik & 95 & & 66 & 22 & & 14 & \\
\hline $\begin{array}{l}\text { Karışdıran-1 } \\
\text { Sağir }\end{array}$ & 17 & 6 & 2 & 7 & 2 & 1,5 & 1 \\
\hline Tatarlar & 15 & 7 & 4 & 3 & & 1,5 & \\
\hline Evrenli & 12 & 7 & 2 & 2 & & 1,5 & \\
\hline Saruhanlı & 7 & 2 & 2 & 3 & 2 & & \\
\hline Sinanlı & 23 & 9 & 9 & 4 & 4 & 2 & \\
\hline Alpullu & 125 & & 91 & 29 & & 9 & \\
\hline Ayvalı & 101 & & 69 & 29 & & 6 & \\
\hline Evrencik & 99 & & 77 & 21 & & 7,5 & \\
\hline Toplam & $\mathbf{1 0 2 9}$ & $\mathbf{1 9 7}$ & $\mathbf{5 5 2}$ & $\mathbf{2 0 5}$ & $\mathbf{1 1 1}$ & $\mathbf{1 6 9}$ & $\mathbf{1 7}$ \\
\hline
\end{tabular}

Bergos kazasında dikkat çeken diğer bir husus ise köylerinin ekseriyetinin selatin ve ümera vakıflarına tahsis edilmiş olmasıdır. Nitekim 44 köyden 30'u selatin ve ümera vakfına tahsis edilmiş olup, bu durum toplam köy sayısına göre \% 68'lik bir orana tekabül etmektedir. Söz konusu vakıflar; Sultan Selim Han Vakfi, Muradiye Vakfi, Koca Mustafa Paşa Vakfi, Rüstem Paşa Vakfi, Pîrî Paşa Vakfı, Şehzade Vakfı, Süleymaniye Vakfı, Hoca Hayreddin Vakfı ve Şehid Mehmed Paşa Vakfı'dır. Yine 5 köy Hadice Sultan hassı olarak kaydedilmiştir. Bunaların dışında Karışdıran-1 Sağir Köyü Ruznamçeci Mustafa'ya zeamet, Sevindik-i Sağir Köyü; Yedikule neferlerine, Sevindik-i Kebir; Hasan Ağa’ya, Akçaköy; Ali Ağa'ya tımar olarak verilmiştir. Kalan Umurca, Çatal, Yörük-i Kafir ve Kayabeyli Köyleri de tımar olarak kaydedilmiş ancak herhangi bir tahsis belirtilmemiştir. Satı Köyü ise Kıbrısçık'ın meşrutasi ${ }^{47}$ olarak görülmektedir.

Bergos kazasına bağlı Karıştıran-1 Sağir Köyü ile Cisr-i Ergene'nin Mestanlar Köyü divan-1 hümayun gedikli kâtiplerinden olup hali hazırda Başruznamçeci Mustafa tarafından zeamet olarak tasarruf edilmekteydi. Söz konusu köylerin her y1l üzerlerine düşen avârız, nüzül, celepkeşân ve cizye vergilerinden başka kendilerinden talep edilen vergileri ödeme imkanları yoktu. Zira Karıştıran-1 Sağir ve Mestanlar köyleri daha önce mamur halde iken fazla talep edilen vergiler sebebiyle perişan hale düştüklerini divan-1 hümayuna gönderdikleri arzda " $z i k r$

47 Meşrûta; camilerin imam, müezzin, hatip gibi hizmetlileriyle hastane, imaret gibi müesseselerde çalışanların ikametleri için tahsis edilen yerlerdir. Pakalın, a.g.e., c. 2, s. 493. 
olunan kurâ' 'mukademâ ma 'mûr iken üzerlerine kayd ve tahrîr olunan avârız nüzül ve celebkeşânların hala perâkende ve perişân olmalarıyla..." şeklinde ifade etmişlerdir. Halbuki Karıştıran-1 Sağir ve Mestanlar köyleri yukarıdaki vergilerin dışında bütün vergilerden "muaf ve müsellem" oldukları, sayım yapılmayan ve kimsenin müdahale etmediği zeamet köylerinden biri olduğu konusunda emr-i şerif verilmesine rağmen mal hırsı için kadılar bunu mahkeme defterlerine kaydetmeyerek mağduriyetlerine sebebiyet vermekteydi. İște bu sebeple Vize, Bergos ve Cisr-i Ergene kadılarına bir hüküm gönderilerek mevkufat ve koyun mukataası defterlerinde kaydolunan vergileri Karıştıran-1 Sagir ve Mestanlar köyleri önceden muayyen olan miktarı (maktû) hazineye teslim ettikleri ve bunun d1şında mükellef olmadıkları sair vergilerin kendilerinden talep edilmemesi emredilmiştir. Bu köylerin muaf olduğu vergiler de hükümde açıkça sıralanmıştır. ${ }^{48}$ Karışdıran Köyü'nün bir özelliği de II. Beyazid'in vefat ettiği yer olmasıdır. II. Beyazid, tahtı oğlu I. Selim'e bırakıp Dimetoka'ya gitmek için yola çıkmış ancak Çorlu yakınlarında Karışdıran Köyü’nde vefat etmiştir (1512). ${ }^{49}$

\section{Bergos Kazasında Selatin ve Ümera Vakıfları ve Köyleri}

Vakıflar, Osmanlı İmparatorluğu'nun amme hizmetleri ve toplumsal yardımlaşma gibi devlet bütçesinden karşılanması gereken işlere tahsis edilmiş hayır müesseseleri olmalarının yanında özellikle Balkanlar'da Türk yerleşme ve yayılması sırasında iskan ve kolonizasyon işleri vazifesi görmüşlerdir. ${ }^{50}$ Osman11'nın Balkanlarda yerleşmesinde erken dönemlerden itibaren fethedilen toprakları Türk-İslam bölgesi yapma gayretiyle cami, mescit, zaviye, türbe ve hamam gibi yapılarla gerçekleştirmeye çalışmaları önemlidir. Ümera tarafından kurulan vakıflarla bugünkü anlamda modern devlet anlayışı gereği devletin yapması gereken din, eğitim, alt yapı, beslenme gibi bir çok toplumsal işleri ifa etmişlerdir. Bu

48 "menzil akçesi ve menzil imdâdiyyesi ve odun ve kömür ve saman ve kazma ve kürek ve beldâr ve bedel-i beldâr ve sürsat ve değirmen ve çayır ve sefer arabası ve bargîr ve bir .... ve dülger ve zâhire ve koyun iştirâsı ve klşlak zâhiresi ve odunu ve samanı ve arpası tekâlifi ve bunun emsâli ile mukaddemâ ve hâlâ verilen evâmir-i şerîfem mûcebince tekâlif-i mezkûreden mu 'âf ve müsellem olup ... ”, KK.d., nr. 2840, s. 36-37; Mukataa kelimesi ile maktû aynı anlamda kullanılmaktadır. Muktaalı toprakları bir kira sözleşmesi temelinde toplayacağı öşürler karşılığ yalnızca toplu olarak belirlenen kira bedelini maktû denilirdi. Halil İnalcık, Osmanlı İmparatorluğu'nun Ekonomik ve Sosyal Tarihi, ed. Halil İnalc1k, Donald Quataert, cilt I, 1300-1600, İstanbul, Eren Yayıncılık, 2004, s. 150.

49 İsmail Hakkı Uzunçarş111, Osmanlı Tarihi, cilt II, Ankara, Türk Tarih Kurumu, 1988, s. 245.

50 Ömer Lütfi Barkan, "İslâm-Türk Mülkiyet Hukuku Tatbikatının Osmanlı İmparatorluğunda Aldığı Şekiller-III: İmparatorluk Devrinde Toprak Mülk ve Vakıfların Hususiyeti”, İstanbul Üniversitesi Hukuk Fakültesi Mecmuası, c. VII/4, İstanbul, 1941, s. 913. 
gaye ile Osmanl, Rumeli'de devlet adamlarına araziler tahsis ederek, ganimetler dağıtarak bunların gelirlerini arttırma yoluna gitmiştir. Feth edilip sultana veya devlete ait olması gereken topraklar ülke içinde refahı arttırmak için büyük kısmı fakirlere ve yolculara hizmet eden vakıflara tesis edilmiştir. ${ }^{51}$ Öyle ki XVI. yüzyıl başlarında Osmanlı'nın bütçe gelirleri içinde vakıf gelirleri \%12'ye tekabül etmekteydi. Bunlardan çoğunluğu padişah ve vezirlere ait vakıflar olup idarî ve malî açıdan birtakım muafiyetlere sahipti. Söz konusu vakıflara muhtelif devlet gelirleri ve köyler vakıf veya temlik edilmiştir. Vakfedilen yerleşim yerlerinde yaşayanların bir çok tekâliften muafiyetleri mevcuttu. ${ }^{52}$

Kuruluştan itibaren Edirne ve İstanbul'a yakınlığg ve güzergah üzerinde bulunması nedeniyle Vize sancağ 1 ve kazalarında çok sayıda selatin, ümera, ulema ve amme vakfi oluşturulmuştu. XVI. yüzyılda Vize'de toplam 43 vakıf olup, bunun $\%$ 20,9 u selatin vakfi, \% 67,5'i ümera ve ulema vakfi ve \% 11,6'sı amme vakfı idi. Bu tarihlerden itibaren Bergos, Vize sanacağına bağlı bir kaza olması hasebiyle köylerinin bir çoğu söz konusu vakıflara tahsis edildiği görülmektedir. ${ }^{53}$ Bergos kazasına bağlı köyler ve bunların tahsis edildiği köyler şunlardır:

Sultan Selim Han Vakfi: Sultan II. Selim'in Edirne'de yaptırdığı cami ve külliyesi için tahsis ettiği vakıf köyler bulunmaktadır. 1603 tarihli Vize Sancağı, Sultan Selim Han Evkaf Defteri'ndeki kayıtlara göre Sarmusakl1, Mukdar, Sayalık, Müsellem, Kara Musalu ve İnanlı köylerinin Sultan Selim Vakfi'na "serbestiyet" ile tahsis edildiği görülmektedir. ${ }^{54} 1712$ yılı avârız defterindeki kayıtlara göre ise Sultan Selim Han Vakfina Bergos kazasından tahsis edilen köy sayısı 6'dan 8'e çıkarken daha önce mevcut olan Müsellem köyü bu defterde yer almamaktadır. 1712 yılı Bergos kazası avârız defterine göre ise Sultan Selim Vakfına tahsis edi-

51 Ahmet Köç, “Osmanlı Devletinde Yönetici Sınıfın Hayırseverliği: Ümera ve Ulema Vakıfları Üzerine Bazı Düşünceler”, Balıkesir Üniversitesi Sosyal Bilimler Enstitüsü Dergisi, c. 19, say1 35, Haziran 2016, s. 306-307.

52 Ömer Lütfi Barkan, “Osmanlı İmparatorluğu Bütçelerine Dair Notlar”, İktisat Fakültesi Mecmuası, c. 15, sayı 1-4, İstanbul, 1953, s. 247.

53 Mehtap Özdeğer, "Vize Kazası Vakıfları -XVI. Yüzyıl Arşiv Kayıtlarına Göre-”, Marmara Üniversitesi İI.I.B.F. Dergisi, c. XXII, sayı 1, 2007, s. 170; Vize sancağındaki selâtîn ve ümera vakıfları ile ilgili çalışma için bk. Volkan Ertürk, "Osmanlı Devletinde Vize Sancağındaki Selâtin ve Ümera Vakıfları (1530-1613)”, Turkish Studies, c. 8/5, Bahar 2013, s. 279-300.

54 "Mahrûs-i Edirne'de binâ eyledikleri câmi'-i şerîfleri evkâf-ı uslûb-ı evkâf-ı selâtin-i mâziye mefrûzu'l-kalem ve maktû'u'l-kadem topră̆ına serbest olup evkâf-ı mezbûre re'âyâsı avârız-ı divâniyyeden ma 'âdâ...”, TKG.KK.VKF. Cd.2121/80, s. 2-6 (29 Zilhicce 1011/9 Haziran 1603). 
len köyler Mukdar, Sarmusaklı, Bali Hocalı-1 Kebir, Bali Hocalı-i Sağir, İnanlı, Sayalık, Kara Musalu, Evrenseki'dir. Nitekim bunlardan Mukdar, Sarmusakl1, Bali-i Hocalı-i Kebîr ve Sagîr köylerinin avârızları tahsis edilen vakıf için mevkufat defteri sureti ile birlikte hazineden gönderildiği ve reayanın avârızlarını eda ettikleri belirtilmektedir. Bu nedenle üzerlerindeki mükellefiyetleri eda ettikleri için söz konusu köylerin reayalarından başkaca bir şey talep etmemeleri konusunda ferman gönderilmiştir. ${ }^{55}$

Süleymaniye Vakfi: Kanûnî Sultan Süleyman'ın İstanbul'da inşa ettirdiği Süleymaniye Cami ve Külliyesi için Rumeli'nin muhtelif yerlerinde çok sayıda vakıf mevcuttur. ${ }^{56}$ Süleymaniye Camii ve Külliyesi'ne ait vakfiyeye göre de tamamı Rumeli'den olmak üzere 217 köy ve 30 mezra vakf edilmiştir. Vakfin 1585-1586 yıllarına ait bilançoları incelendiğinde söz konusu köylerden 75'i Gelibolu, 124 köy Paşa sancağının Filibe, Drama, Kavala, Yenice-i Karasu ve Samakov kazalarında, 6 köy Çirmen kazasında ve 13 köy ise Vize kazasında bulunmakta idi. ${ }^{57}$ 1712 yılında Vize sancağına bağlı Bergos kazasının Taşlı ve Çengerli köylerinin avârız gelirlerin Süleymaniye Vakfına tahsis edildiği görülmektedir.

Koca Mustafa Paşa Vakfi: Koca Mustafa Paşa, II. Beyazid dönemi sadrazamlarından olup 1512 yılında idam edilmiştir. ${ }^{58}$ Koca Mustafa Paşa, sağlığında iken kendi vakfını kurmuş ve bunun 1505-1506 yıllarında tescil edildiği tahmin edilmektedir. Vakfiyesinde Koca Mustafa Paşa Külliyesi'ndeki binalar ve fark11 yerlerde satın alıp vakfettiği mülkler konu edilmektedir. Hem vakıf ve hem akarlarının ağırlığı İstanbul'da olmak üzere Rumeli'nin muhtelif kazalarında da mülkleri mevcuttur. ${ }^{59}$ Rumeli'de vakfına tahsis edilen yerler arasında Vize'nin bazı köyleri de mevcuttur. İstanbul Vakıfları Tahrir Defterinde "Karye-i Pınarbaşı ve tevâbi 'uhâ tâbi '-i kazâ-i Vize" şeklinde zikr edilmekte, başkaca bir köy bulunmamaktadır. ${ }^{60}$ Ancak 1712 tarihli avârız defterinde ise Koca Mustafa Paşa Vakfı'na Paşa, Turgutbeyli ve Pınarbaşı köylerinin tahsis edildiği görülmektedir. ${ }^{61}$

55 KK.d., nr. 2840, s. 18 (5 Rebîülâhir 1123/23 May1s 1711).

56 Gökbilgin, Paşa Livası, s. 497.

57 Süleymaniye Vakfının tescil tarihi 6 Temmuz 1557 olarak kayıtlarda bulunmaktadır. Ömer Lürfi Barkan, "Süleymaniye Cami ve İmareti Tesislerine Ait Y1llık Bir Muhasebe Bilançosu (993-994/1585-1586)", Vakıflar Dergisi, sayı IX, (T1pk1 Basım), Ankara, 2006, s. 114.

58 Feridun M. Emecen, "Koca Mustafa Paşa”, TDVIA, c. 26, Ankara, 2002, s. 131-133.

59 Nazif Öztürk, “Koca Mustafa Paşa Vakıfları ve Külliyesi”, Vakıflar Dergisi, sayı 28, Ankara, 2004, s. 11-14.

60 Ömer Lütfi Barkan-Ekrem Hakkı Ayverdi, Istanbul Vakıfları Tahrir Defteri 953 (1546) Târihli, İstanbul, Baha Matbas1, 1970, s. 366-367.

61 KK.d., nr. 2840, s. 22-24. 
Şehzade Vakfi (Şehzade Sultan Mehmed Vakfi): Şehzade Sultan Mehmed, Kanûnî Sultan Süleyman'ın 1522 yılında Hürrem Sultan'dan olan oğludur. Kanûnî'nin çok sevdiği oğlu Mehmed, kendisinden sonra en güçlü taht aday1 olarak görülmekteydi. Ancak Kanûnî'nin Macar seferi dönüşünde Edirne'de bulunduğu sirada Manisa'da idarecilik yapmakta olan oğlu Mehmed aniden vefat etmiştir (1543). ${ }^{62}$ Kanûnî, çok sevdiği oğlu Mehmed için türbe, yanına hayrat olarak cami, imaret ve medrese yaptırdı. Bu eserlerin idamesi için de Kanûnî Sultan Süleyman tarafından 1546-1547 yıllarında vakfiyeler hazırlatılmıştır. ${ }^{63}$ Şehzade Mehmed Han için yaptırılan külliyenin gelirleri için İstanbul ve Rumeli'de bir çok mülk vakfedilmiştir. Rumeli'de vakfedilenler arasında 51 köy, 3 mezra ve 7 çiftlik bulunmaktadır. Bunlardan Pınarhisar'a bağlı Bedir ve Kuruca Ali köyleri de Şehzade Sultan Mehmed Vakfı'na tahsis edilmişti. ${ }^{64} 1712$ yılı avârız defterine göre söz konusu köylerin Bergos'a bağl1 olup yine gelirlerinin Şehzade Mehmed Vakfina tahsis edildiği "Karye-i Bedir an-evkâf-ı Şehzâde Der-Asitâne” ibaresinden anlaşılmaktadır. ${ }^{65}$

Muradiye Vakfi: Sultan II. Murad tarafindan Edirne'nin “Muradiye” denilen semtinde bir cami ve imaret yaptırılmış ve buranın masrafları için kurulan vakfa bir çok mülk tahsis edilmişti. Daha sonra buraya bir de mevlevihâne yaptırdığı bilinmektedir. Muradiye imareti vakfina Babaeski, Vize, Hayrabolu, İpsala ve Gümülcine'de bir çok gelir tahsis edilmişti. Söz konusu sancak ve kazaların müslüman ve gayr-i müslim çok sayıda köylerinin her türlü vergileri Muradiye Vakfının gelirlerini teşkil etmekteydi. ${ }^{66} 1712$ yılı avârız defteri kayıtlarına göre de Bergos kazasının Eyneller, Misinli, Köpeklü ve Mir Ali köylerinin avârız vergilerinin Muradiye Vakfına tahsis edildiği görülmektedir.

Hoca Hayreddin Vakfi: Hoca Hayreddin, Fatih Sultan Mehmed'e hocalık yapmış dönemin muteber müderrislerindendir. Vakıf defterinde kesin bir vakfiye tarihi olmamakla birlikte Fatih'te Hoca Hayreddin Medresesi, mektebi ve imareti yanında Üç Mihrablı Cami vakıf olarak yaptırdığı eserlerdendir. Bunlar için kurduğu Hoca Hayreddin Vakfı için İstanbul'da bulunan mülkleri dışında Edirne ve Vize'de de tahsis ettiği yerler bulunmaktadır. Bunlar arasında Vize'nin Ahmedbey köyünün geliri Hoca Hayreddin Bey Vakfı'na tahsis edilmiştir. ${ }^{67} 1712$ yılında

62 Feridun M. Emecen, “Süleyman I”, TDVİA, c. 38, İstanbul, 2010, s. 68.

63 Yusuf Sağır, "Vakfiyelerine ve Belgelerine Göre Şehzâde Mehmed Vakıfları", Uluslararası Sosyal Araştırmalar Dergisi, c. 9, say1 43 Nisan 2016, s. 922.

64 Sağır, a.g.m, s. 931.

65 KK.d., nr. 2840, s. 25-26.

66 Gökbilgin, Paşa Livası, s. 203-210.

67 "Karye-i Ahmed Beğ Tâbi'i Kazâ-ı Vize”, Barkan-Ayverdi, a.g.e., s. 180; Ekrem Hakkı Ay- 
38 hânenin bulunduğu ve tamamı gayr-i müslim olan Ahmedbey köyünün Hoca Hayreddin Vakfı'na tahsis edildiği görülmektedir. ${ }^{68}$

Rüstem Paşa Vakfi: Rüstem Paşa, Kanûnî Sultan Süleyman döneminde 15441553 ve $1555-1561$ tarihleri arasında toplam 14,5 yıl kadar sadrazamlık yapmış bir Osmanlı devlet adamıdır. Anadolu, Rumeli ve Arabistan'da yaptırdığı çok sayıda hayır eseri ve bunlar için temlik ettiği mülkler mevcuttur. ${ }^{69}$ Karışdıran Köyünde 1546-1547 yıllarında Rüstem Paşa evkafı olarak yaptırılan bir cami, hamam, 10 dükkan ve çeşme mevcuttur. ${ }^{70}$ Bergos kazasına bağlı 20 Nisan 1549 tarihinde Çiftlik ve 8-17 Nisan 1551 tarihinde Karışdıran-i Kebir köyleri Rüstem Paşa Vakfi'na vakf ve temlik edilmiştir. Bu sebeple gelirleri söz konusu vakfa ait olup daha önce de avârız ve nüzül vergilerini vakıf mütevellisi maktû olarak hazineye teslim etmekteydi. ${ }^{71}$

Pîrî Mehmed Paşa Vakfi: Pîrî Mehmed Paşa, 1518-1522 yılları arasında hem Yavuz Sultan Selim'in son döneminde hem de Kanûnî Sultan Süleyman'in ilk yıllarında veziriazamlık yapmıştır. İstanbul Zeyrek’te cami, mektep, medrese, Silivri'de cami, misafirhâne, imaret, mektep ve medreseden oluşan külliye yaptırmıştır. Bunun dışında çoğunluğu Rumeli olmak üzere bir çok hayır eseri vardır. ${ }^{72}$ Bunlar içinde XVI. asır sonlarında yapılan tahrirde Hayrabolu kazasına bağl1 yıllık geliri 2.500 akçe olan Oklağulu köyü de mevcuttur. Ancak vakfiyede de görüldüğü üzere söz konusu köyün gelirlerinin yarısının tahsis edildiğini "Nâhiye-i Hayrabolı Karye-i Oklağulu nısf hisse" ibaresinden anlaşılmaktadır. ${ }^{73}$ Zaten gelirlerinin iki ayrı vakfa tahsis edildiği incelenen avârız defterinde açıktır. Nitekim 1712 yılı avârız Defterinde Oklağulu Köyü "Karye-i Oklağulu an-vakfPîrî Paşa ve Rüstem Paşa" şeklinde zik edilerek hem Rüstem Paşa hem de Pîrî Mehmed Paşa vakfına tahsis edildiği görülmektedir. ${ }^{74}$

Şehid Mehmed Paşa Vakfi: Sokullu Mehmed Paşa'nın kurduğu bir vakıftır. Paşa sancağına bağlı kazalarda vakfa gelir temin eden köyler olup, burala-

verdi, Osmanlı Mimarisinde Fatih Devri 855-886 (1451-1481), c. III, İstanbul, Baha Matbas1, 1973, s. 510-511.

68 KK.d., nr. 2840, s. 27-28.

69 Erhan Afyoncu, "Rüstem Paşa”, TDVIA, c. 35, İstanbul, 2008, s. 288-289.

70 Evliya Çelebi b. Derviş Mehmed Zillî, Evliya Çelebi Seyatnâmesi, 6. Kitap, haz. Seyit Ali Kahraman, Yücel Dağlı, 1. bs., İstanbul, Yapı Kredi Yayınları, 2002, s. 88.

71 Mufassal Avârız defterinde Karye-i Çiftlik'in diğer adı Tunabeyli Çiftliği olarak geçmektedir. KK.d., nr. 2840, s. 33; Arslantürk, a.g.t, s. 68.

72 Yusuf Küçükdağ, "Pîrî Mehmed Paşa", TDVIA, c. 34, İstanbul, 2007, s. 280-281.

73 Barkan-Ayverdi, a.g.e., s. 427-428.

74 KK.d., nr. 2840, s. 24. 
rın reayasında "mu 'âfnâme" mevcuttur. Çok sayıda hayır eserinden dolayı yine muhtelif yerlerde vakıfları olduğu anlaşılmaktadır. Edirne'deki bir vafiyesinde vakıf gelirleri ve masraf yerlerini sayarken buralardan fazla kalan gelirlerin Lüleburgaz'daki cami, imaret, medrese ve müştemilatına sarf edilmesini istemiştir. ${ }^{75}$ Nitekim Bergos'ta yer alan Sokullu Mehmed Paşa Cami ve Külliyesi onun hayratıdır. ${ }^{76} 1712$ yılı avârız tahrirlerinde de Bergos kazasının Tartarlar, Evrenseki, Saruhanlı, Sinanlı, Apullu, Ayvalı ve Evrencik köylerinin gelirleri Şehid Mehmed Paşa'nın yaptırdığı cami, medrese ve imaretlerine vakıf olarak tahsis edildiğini görülmektedir. Bu sebeple de söz konusu köylerin reyası her türlü avârız ve nüzül vergilerinden muaf kılınmıştır. Bu durum Bergos mufassal avârız defterinde "cem 'i arâzi ve mezâri 'i ve tevâbi' ve levâhiki ile vezir-i müşârun-ileyhe temlîk olunup min-külli vücûh serbest mefrûzu'l-kalem ve maktû'ul-kadem ve avârız ve nüzül ve amme- $i$ tekâlifden mu 'âf olmak üzere..." şeklinde açıkça ifade edilmiştir. ${ }^{77}$ Zira Osmanlı padişahları istedikleri zaman istedikleri kişilere birtakım köyleri bütün hukuk ve vergileriyle birlikte ebediyet ve serbestiyet üzere temlik hak ve selahiyetine sahiptirler. Temliklerin çoğu da hibe ve bağış şeklinde gerçekleşirdi. ${ }^{78}$ Söz konusu mülk ve vakıflar serbestiyet üzere bağışlandığından vergi tahakkuk etmez ve hiçbir şekilde müdahale edilemezdi. ${ }^{79}$

Hadice Sultan Hasst: 1712 yılı Bergos avârız defterinde 5 köy Hadice Sultan hass1 olarak görülmektedir. Ancak defterde Hadice Sultan hakkında herhangi bir bilgi verilmemiştir. Gelirleri Hadice Sultan hassına tahsis edilen köyler; Seydiler, Kara Danışmendlü, Düğüncübaşı, Karaağaç, Müsellem’dir.

\section{Sonuç}

Bergos kazasında 1712 yılında yapılan tahrir sonucunda 192,5 avârız hânesi tespit edilmiştir. Söz konusu tahrirle birlikte merkezde 5 mahalle ve kazaya bağlı 44 köyün öncelikle muaf ve gayr-i muaf ayrımı yapılmadan vergi tabanına esas olan tüm nüfusu deftere kaydedilmiştir. Yine merkeze bağlı Yahudi ve Kıbtî cemaati de "hariç ez-defter" olduğu için ilk defa bu tahrire dahil edilmiştir. Mufassal sayımda vergi tabanına esas olan kaza ve köylerdeki nüfusun askerî, dinî görevli, çiftlik sahipleri ile birlikte özürlü, dul, yaşlı, çocuk, yetim, yaralı, felç vb. tüm durumları belirtilmiştir. Kaza nüfusunun \% 79,3'ü köylerde \% 20,7'si merkezde yaşamaktadır. Köylerde sadece müslüman veya sadece gayr-i müslim

75 Gökbilgin, Paşa Livası, s. 508-109.

76 Evliya Çelebi, a.g.e., 3. Kitap, s. 172.

77 KK.d., nr. 2840, s. 37.

78 Barkan, “Toprak Mülk ve Vakıfların Hususiyeti”, s. 922.

79 İnalcık, Devlet-i Aliyye-I, s. 331. 
nüfus yaşamaktadır. Yani müslüman ve gayr-i müslim nüfus genel olarak ayrı yaşamaktadır. Müslüman köylerinde nüfus yoğunluğu düşük iken gayr-i müslim köylerde ise yoğunluk fazladır.

Bergos'ta dikkat çeken durumlardan biri müslüman köylerinde askerî sınıf mensubu nüfusun yüksek olmasıdır. Bunda Bergos'un İstanbul-Edirne menzil güzergahında olması hasebiyle tercih edilen bir mahal olmasının yanında Sokullu Mehmed Paşa Külliyesi'nin varlığ 1 ve buna bağlı çok sayıda kişinin berat sahibi olarak istihdam edilmesi önemli bir etkendir. Yine Bergos'un İstanbul'a yakın olması nedeniyle köylerin çoğunluğunun selatin ve ümera vakıflarına tahsis edilmiş olması da dikkat çekmektedir. Nitekim Bergos'un 44 köyünden 30'unun doğrudan selatin ve ümera vakıflarına tahsis edilmiş olması bunu teyit eden bir durumdur. Diğerleri de birtakım kimselere doğrudan has, zeamet ve tımar olarak verilmiştir. XVI. ve XVII. yüzyılda Rumeli bölgesinde ön plana çıkan ve Osmanlı toprak sisteminin bozularak çiftliklere dönüşmesinin somut örneği Bergos köylerinde görülmekte olup 111 çiftlik bulunmaktadır. 


\section{Kaynakça}

Başkanlık Osmanlı Arşivi (BOA), Kamil Kepeci Defterleri (KK.d.), nr. 2840.

Tapu Kadastro Genel Müdürlüğü Kuyud-1 Kadime Arşivi Vakfiye Defterleri (TKG.KK.VKF. Cd.,) nr. 2121/80.

30 Numaralı Muhasebe-i Vilayet-i Rûm-ili Defteri (937/1530)-I, Ankara, Devlet Arşivleri Genel Müdürlüğü Yayınları, 2001.

370 Numaralı Muhasebe-i Vilayet-i Rum-ili Defteri (937/1530), Ankara, Devlet Arşivleri Genel Müdürlüğü, 2001.

Afyoncu, Erhan, "Rüstem Paşa", Türkiye Diyanet Vakfi Íslam Ansiklopedisi, c. 35, İstanbul, 2008.

Aktepe, Münir, "XVII. Asra Ait İstanbul Kazâsı Avârız Defteri”, İstanbul Enstitüsü Dergisi-III, İstanbul, 1957.

Altunan, Sema, "XVII. Yüzyıl Sonlarında İstanbul-Edirne Arasındaki Menziller ve Bazı Menzilkeş Köyler”, Tarih Araştırmaları Dergisi, c. 25, sayı 39, Ankara, 2006.

Arslantürk, Hacı Ahmet, "Bir Bürokrat ve Yatırımcı Olarak Kanûnî Sultan Süleyman'ın Veziriazamı Rüstem Paşa”, (Yayımlanmamış Doktora Tezi), Marmara Üniversitesi Sosyal Bilimler Enstitüsü, İstanbul, 2011.

Ayverdi, Ekrem Hakk1, Osmanlı Mimarisinde Fatih Devri 855-886 (14511481), c. III, İstanbul, Baha Matbas1, 1973.

Barkan, Ömer Lütfi, “Türkiye'de İmparatorluk Devirlerinin Büyük Nüfus ve Arazi Tahrirleri ve Hakana Mahsus İstatistik Defterleri (I)", İstanbul Üniversitesi İktisat Fakültesi Mecmuası, c. II/1, İstanbul, 1941.

, “Türkiye'de İmparatorluk Devirlerinin Nüfus ve Arazi Tahrirleri ve Hakana Mahsus İstatistik Defterleri (II), İstanbul Üniversitesi İktisat Fakültesi Mecmuası, c. II/2, İstanbul, 1941.

, "İslâm-Türk Mülkiyet Hukuku Tatbikatının Osmanlı İmparatorluğunda Aldığı Şekiller-III: İmparatorluk Devrinde Toprak Mülk ve Vakıfların Hususiyeti", İstanbul Üniversitesi Hukuk Fakültesi Mecmuası, c. VII/4, İstanbul, 1941.

, "Osmanlı İmparatorluğu Bütçelerine Dair Notlar", İktisat Fakültesi Mecmuası, c. 15, say1 1-4, İstanbul, 1953.

, "Süleymaniye Cami ve İmareti Tesislerine Ait Yıllık Bir Muhasebe Bilançosu (993-994/1585-1586)”, Vakıflar Dergisi, sayı IX, (Tıpk1 Basım), Ankara, 2006. 
simevi, 1979.

, “Avârız”, İslam Ansiklopedisi, c. 2, İstanbul, Milli Eğitim Ba-

Barkan, Ömer Lütfi-Ayverdi, Ekrem Hakk1, İstanbul Vakıfları Tahrir Defteri 953 (1546) Târihli, İstanbul, Baha Matbası, 1970.

Çakar, Enver, "Kanûni Sultan Süleyman Kanun-nâmesine Göre 1522 Y1lında Osmanlı İmparatorluğu'nun İdari Taksimatı", Firat Üniversitesi Sosyal Bilimler Dergisi, c. 12/1, Elazı̆̆, 2002.

, "17. Yüzyılın İkinci Yarısında Antakya Kazâsında İskân ve Nüfus (1678/1089 tarihli Avârız-hâne Defterine Göre)”, Belleten, c. LXVIII, say1 252, Ağustos 2004.

Emecen, Feridun M., "Koca Mustafa Paşa", Türkiye Diyanet Vakfi İslam Ansiklopedisi, c. 26, Ankara, 2002.

tanbul, 1996.

, "Mufassaldan İcmale", Osmanlı Araştırmaları, sayı XVI, İs, "Süleyman I", Türkiye Diyanet Vakfi İslam Ansiklopedisi, c. 38, İstanbul, 2010.

Ertürk, Volkan, "Osmanlı Devletinde Vize Sancağındaki Selâtin ve Ümera Vakıfları (1530-1613)”, Turkish Studies, c. 8/5, Bahar 2013.

, "1642 Tarihli Avârız Defterlerine Göre Vize Sancağı Kazaları", EKEV Akademi Dergisi, y11 17, say1 57, Güz 2013.

Evliya Çelebi b. Derviş Mehmed Zillî, Evliya Çelebi Seyatnâmesi, 3. Kitap, haz. Seyit Ali Kahraman, Yücel Dağlı, İstanbul, Yapı Kredi Yayınları, 2006.

, Evliya Çelebi Seyatnâmesi, 6. Kitap, haz. Seyit Ali Kahraman, Yücel Dağlı, İstanbul, Yapı Kredi Yayınları, 2002.

Gök, Eren Bahri, "89 Numaralı Mühimme Defteri”, (Yayımlanmamış Yüksek Lisans Tezi), Marmara Üniversitesi Türkiyat Araştırmaları Enstitüsü, İstanbul, 2003.

Gökbilgin, M. Tayyip, Rumeli'de Yörükler, Tatarlar ve Evlad-ı Fatihan, İstanbul, İstanbul Üniversitesi Edebiyat Fakültesi Yayınları, 1957.

, XV- XVI.Asırlarda Edirne ve Paşa Livası (Vakıflar-Mülkler-Muktaalar), İstanbul, İstanbul Üniversitesi Edebiyat Fakültesi Yayınları, 1952.

, "Kanûnî Sultan Süleyman Devri Başlarında Rumeli Eyaleti, Livaları, Şehir ve Kasabaları", Belleten, c. 20, sayı 78, Ankara, 1956. 
Gökçe, Turan, "Osmanlı Nüfus ve İskan Kaynaklarından "Mufassal-İcmal" Avârız Defterleri ve 1701-1709 Tarihli Gümülcine Kazâsı Örnekleri”, Tarih İncelemeleri Dergisi, c. XX/I, Temmuz 2005.

, "Bir Tahrir Üç Defter: 1697-1698 Avârız Defterlerine Göre Siroz (Serez) Şehri”, Türk Dünyası İncelemeleri Dergisi, c. VI, say1 1, İzmir 2006.

Göyünç, Nejat, "Hâne", Türkiye Diyanet Vakfi İslam Ansiklopedisi, c. 15, İstanbul, 1997.

Güçer, Lütfi, XVI.-XVII. Asırlarda Osmanlı Imparatorluğunda Hububat Meselesi ve Hububattan Alınan Vergiler, İstanbul, İstanbul Üniversitesi İktisat Fakültesi, 1964.

İnalc1k, Halil, Devlet-i Aliyye, Osmanlı İmparatorluğu Üzerine Araştırmalar-I, Klasik Dönem (1302-1606), İstanbul, Türkiye İş Bankası Kültür Yayınları, 2009.

Türk Tarih Kurumu, 1987.

, Osmanlı Imparatorluğu'nun Ekonomik ve Sosyal Tarihi, ed. Halil İnalc1k, Donald Quataert, cilt I, 1300-1600, İstanbul, Eren Yayınc1lık, 2004. , "Çiftliklerin Doğuşu: Devlet, Toprak Sahibi ve Kiracılar", Osmanlı Toprak Mülkiyeti ve Ticarî Tarım, ed. Çağlar Keyder, Faruk Tabak, İstanbul, Tarih Vakfi Yurt Yayınları, 1998.

, “Osmanlı'da Raiyyet Rüsûmu”, Belleten, c. XXXIII/92, 1959.

İnbaş1, Mehmet, 17. Yüzyıl Kayseri Avârız ve Cizye Defterleri, Kayseri, Kayseri Büyükşehir Belediyesi Kültür Yayınları, 2011.

, "1642 Tarihli Avârız Defterine Erzurum Şehri”, Türk Kültürü Incelemeleri Dergisi, say1 4, İstanbul, 2001.

İpşirli, Mehmet, "Câbî”, Türkiye Diyanet Vakfi İslam Ansiklopedisi, c. 6, İstanbul, 1992.

Kılıç, Orhan, "Batı Karadeniz Kıyısında Bir Osmanlı Eyaleti: Özi/Silistre (İdari Taksimat ve Yönetim)”, Karadeniz İncelemeleri Dergisi, say1 23, 2017.

Kiel, Machiel, "Lüleburgaz", Türkiye Diyanet Vakfi İslam Ansiklopedisi, c. 27, Ankara, 2003.

Köç, Ahmet, "Osmanlı Devletinde Yönetici Sınıfın Hayırseverliği: Ümera ve Ulema Vakıfları Üzerine Bazı Düşünceler”, Balıkesir Üniversitesi Sosyal Bilimler Enstitüsü Dergisi, c. 19, sayı 35, Haziran 2016. 
Kul, Eyüp, "1642 Tarihli Avârız Defterine Göre Şiran Kazası ve Köyleri”, Atatürk Üniversitesi Türkiyat Araştırmaları Dergisi, sayı 44, Erzurum, 2010.

Küçükdağ, Yusuf, "Pîrî Mehmed Paşa”, Türkiye Diyanet Vakfi İslam Ansiklopedisi, c. 34, İstanbul, 2007.

Küçükkaya, Gülçin, "Mimar Sinan Dönemi İstanbul-Belgrad Arası Menzil Yapıları Hakkında Bir Deneme”, Vakıflar Dergisi, sayı 21, Ankara, 1990.

Küpeli, Özer, "Klasik Tahrirden Avârız Tahririne Geçiş Sürecinde Tipik Bir Örnek: 1604 Tarihli Manyas Avârız Defteri”, CIÉPO Osmanlı Öncesi ve Osmanlı Araştırmaları Uluslararası Komitesi XVII. Sempozyumu Bildirileri (Trabzon, 1823 Eylül 2006), haz. Kenan İnan, Yücel Dursun, Trabzon, Karadeniz Araştırmaları Enstitüsü Yayınları, 2011.

Müderrisoğlu, Fatih, "Menzil Kavramı ve Osmanlı Devletinde Menzil Yerleşimleri”, Türkler, ed. Hasan Celal Güzel, Kemal Çiçek, Salim Koca, c. 10, Ankara, Yeni Türkiye Yayınları, 2002.

, "Osmanlı İmparatorluğunda Menzil Yolları ve Menzil Külliyeleri”, Osmanll, ed. Güler Eren, c. 10, Ankara, Yeni Türkiye Yayınları, 2002.

Öz, Mehmet, “Tahrir”, Türkiye Diyanet Vakfi İslam Ansiklopedisi, c. 39, İstanbul, 2010.

Özdeğer, Mehtap, "Vize Kazası Vakıfları -XVI. Yüzyıl Arşiv Kayıtlarına Göre-“, Marmara Üniversitesi İ.I.B.F. Dergisi, c. XXII, sayı 1, 2007.

, "16. Yüzyılda Vize Sancağının Demografik ve Ekonomik Yapısı”, Türk Dünyası Araştırmaları Dergisi, sayı 132, Haziran 2001.

Özel, Oktay, “17. Yüzyıl Osmanlı Demografi ve İskan Tarihi İçin Önemli Bir Kaynak: "Mufassal Avârız Defterleri”, XII. Türk Tarih Kongresi, (12-16 Eylül 1994), Kongreye Sunulan Bildiriler, c. III, Ankara, 1994.

, “Avârız ve Cizye Defterleri”, Osmanlı Devleti'nde Bilgi ve İstatistik, der. Halil İnalcık, Şevket Pamuk, Ankara, Başbakanlık Devlet İstatistik Enstitüsü, 2000.

Öztürk, Mustafa, “1675-1676 (h. 1086) Şam Avârızhâne Defteri”, Fırat Üniversitesi Orta Doğu Araştırmaları Dergisi, c. II, sayı 2, Elazı̆̆, 2004.

Öztürk, Nazif, “Koca Mustafa Paşa Vakıfları ve Külliyesi”, Vakıflar Dergisi, say1 28, Ankara, 2004.

Pakalın, Mehmet Zeki, Osmanlı Tarih Deyimleri ve Terimleri Sözlüğü, c. 2, İstanbul, Milli Eğitim Basımevi, 1983. 
Purodran, Nihan, “Temettuat Defterlerine Göre Lüleburagz'nn Sosyo-Ekonomik ve Demografik Yapısı”, (Yayımlanmamış Yüksek Lisans Tezi), Trakya Üniversitesi Sosyal Bilimler Enstitüsü, Edirne, 2010.

Rumeli Eyaleti (1514-1550), Ankara, Devlet Arşivleri Genel Müdürlüğü, 2013.

Sağır, Yusuf, "Vakfiyelerine ve Belgelerine Göre Şehzâde Mehmed Vakıfları”, Uluslararası Sosyal Araştırmalar Dergisi, c. 9, sayı 43, Nisan 2016.

Sezer, Musa, "Avârız Kayıtlarına Göre XVII. ve XVIII. Yüzyıllarda Karinabad Kazâsı”, History Studies, c. 10, say1 9, Aralık 2018.

Tabakoğlu, Ahmet, “Klasik Dönemde Osmanlı Ekonomisi”, Türkler, ed. Hasan Celal Güzel, Kemal Çiçek, Salim Koca, c. 10, Ankara, Yeni Türkiye Yayınları, 2002.

Topçular Katibi Abdülkâdir (Kadrî) Efendi Tarihi (Metin ve Tahlîl), c. II, haz. Ziya Y1lmazer, Ankara, Türk Tarih Kurumu, 2003.

Uzunçarş11, İsmail Hakkı, Osmanlı Tarihi, c. II, Ankara, Türk Tarih Kurumu, 1988.

, Osmanlı Tarihi, c. IV, Ankara, Türk Tarih Kurumu, 1983.

Ünal, Mehmet Ali, “1646 (1056) Tarihli Harput Kazâsı Avârız Defteri”, Tarih İncelemeleri Dergisi, c. XII, İzmir, 1997.

Yarc1, Güler, "Osmanlı Yönetiminde Vize Sancağı: Nüfus ve İskan”, IV. Vize Tarih ve Kültür Sempozyumu (17-18 Ekim 2008, Vize), Bildiriler, ed. Güler Yarc1, Hüseyin Salman, Vize, 2015.

, “Arşiv Belgeleri Işığında Vize (XVIII.-XX. yy), Vize II. Tarih ve Kültür Seтроzуити, Vize, 10 Haziran 2005. 
Ek-1: Bergos Kazası Köyleri Nefer, Müslüman ve Gayr-i Müslim Nüfus

\begin{tabular}{|c|c|c|c|c|c|}
\hline Karye Adı & $\begin{array}{l}\text { Tahrîre } \\
\text { Tabi } \\
\text { Nüfus }\end{array}$ & \begin{tabular}{|l|} 
Avârıza \\
Tabi \\
Nüfus
\end{tabular} & Müslüman & $\begin{array}{l}\text { Gayr-i } \\
\text { Müslim }\end{array}$ & Vakıf/Zeamet/Timar \\
\hline Mukdar & 13 & 7 & 13 & - & Sultan Selim Han Vakfi \\
\hline Sarmusaklı & 8 & 7 & 8 & - & Sultan Selim Han Vakfi \\
\hline Bali Hocalı Kebir & 11 & 8 & 11 & - & Sultan Selim Han Vakfı \\
\hline Bali Hocalı Sağir & 11 & 8 & 11 & - & Sultan Selim Han Vakfı \\
\hline İnanlı & 9 & 2 & 9 & - & Sultan Selim Han Vakfı \\
\hline Sayalık & 29 & 13 & 29 & - & Sultan Selim Han Vakfı \\
\hline Kara Musalu & 17 & 9 & 17 & - & Sultan Selim Han Vakfı \\
\hline Evrenseki & 18 & 11 & 18 & - & Sultan Selim Han Vakfi \\
\hline Seydiler & 15 & 6 & 15 & - & Hadice Sultan Hassı \\
\hline Kara Danışmendli & 16 & 9 & 16 & - & Hadice Sultan Hassı \\
\hline Karaağaç & 19 & 11 & 19 & - & Hadice Sultan Hassı \\
\hline Müsellem & 22 & 12 & 22 & - & Hadice Sultan Hassı \\
\hline Sevindik-i Sağir & 18 & 12 & 18 & - & T1mar/Yedikule neferatı \\
\hline Oklağulu & 16 & 10 & 16 & - & $\begin{array}{l}\text { Pîrî Paşa ve Rüstem } \\
\text { Paşa Vakfı }\end{array}$ \\
\hline Sevindik-i Kebir & 13 & 8 & 13 & - & Timar/Hasan Ağa \\
\hline Taşlı & 14 & 10 & 14 & - & Süleymaniye Vakfı \\
\hline Çengerli & 15 & 10 & 15 & - & Süleymaniye Vakfı \\
\hline Paşa & 11 & & 11 & - & $\begin{array}{l}\text { Koca Mustafa Paşa } \\
\text { Vakfi }\end{array}$ \\
\hline Turgutbeyli & 30 & 16 & 17 & 13 & $\begin{array}{l}\text { Koca Mustafa Paşa } \\
\text { Vakfi }\end{array}$ \\
\hline Pınarbaşı & 6 & 2 & 6 & - & $\begin{array}{l}\text { Koca Musatafa Paşa } \\
\text { Vakfi/Havâs }\end{array}$ \\
\hline Bedir & 13 & 5 & 13 & - & Şehzadegan Vakfi \\
\hline Kuruca Ali & 5 & 3 & 5 & - & Şehzadegan Vakfi \\
\hline Eyneller & 13 & 6 & 13 & - & Muradiye Vakfi/Edirne \\
\hline Misinli & 60 & 52 & 1 & 59 & Muradiye Vakfi/Edirne \\
\hline Köpeklü & 3 & 3 & 3 & - & Muradiye Vakfi/Edirne \\
\hline
\end{tabular}




\begin{tabular}{|c|c|c|c|c|c|}
\hline Düğüncübaş1 & 4 & 4 & 4 & - & Hadice Sultan Hassı \\
\hline Ahmedbey & 38 & 26 & - & 38 & Hoca Hayreddin Vakfi \\
\hline Akçaköy & 9 & 3 & 9 & - & Tımar/Ali Ağa \\
\hline Umurca & 17 & 11 & 17 & - & Timar \\
\hline Yörük-i Kafir & 3 & 1 & 3 & - & Tımar/Subaşı \\
\hline Kayabeyli & 11 & 5 & 11 & - & Timar \\
\hline Mir Ali & 15 & 7 & 15 & - & Muradiye Vakfi/Edirne \\
\hline Çiftlik & 95 & 56 & - & 95 & Rüstem Paşa Vakfı \\
\hline Karışdıran-1 Kebir & 33 & 11 & 33 & - & Rüstem Paşa Vakfı \\
\hline Karışdıran-1 Sağir & 17 & 3 & 17 & - & Zeamet/Mustafa \\
\hline Tatarlar & 15 & 5 & 15 & - & $\begin{array}{l}\text { Şehid Mehmed Paşa } \\
\text { Vakfı }\end{array}$ \\
\hline Saruhanlı & 7 & 2 & 7 & - & $\begin{array}{l}\text { Şehid Mehmed Paşa } \\
\text { Vakfı }\end{array}$ \\
\hline Sinanlı & 23 & 17 & 23 & - & $\begin{array}{l}\text { Şehid Mehmed Paşa } \\
\text { Vakfı }\end{array}$ \\
\hline Evrenli & 12 & 7 & 12 & - & $\begin{array}{l}\text { Şehid Mehmed Paşa } \\
\text { Vakfı }\end{array}$ \\
\hline Alpullu & 125 & 87 & - & 125 & $\begin{array}{l}\text { Şehid Mehmed Paşa } \\
\text { Vakfı }\end{array}$ \\
\hline Ayvalı & 101 & 64 & - & 101 & $\begin{array}{l}\text { Şehid Mehmed Paşa } \\
\text { Vakfı }\end{array}$ \\
\hline Evrencik & 99 & 76 & - & 99 & $\begin{array}{l}\text { Şehid Mehmed Paşa } \\
\text { Vakfı }\end{array}$ \\
\hline Toplam & 1029 & 625 & 499 & 530 & \\
\hline
\end{tabular}

